University of Louisville

ThinkIR: The University of Louisville's Institutional Repository

$5-2015$

\title{
More than "moon gold and marbles" : rationalization, reform, and the transformation of the American circus, 1900-1940.
}

Matt Holdzkom 1981-

University of Louisville

Follow this and additional works at: https://ir.library.louisville.edu/etd

Part of the History Commons

\section{Recommended Citation}

Holdzkom, Matt 1981-, "More than "moon gold and marbles" : rationalization, reform, and the transformation of the American circus, 1900-1940." (2015). Electronic Theses and Dissertations. Paper 2142.

https://doi.org/10.18297/etd/2142

This Master's Thesis is brought to you for free and open access by ThinkIR: The University of Louisville's Institutional Repository. It has been accepted for inclusion in Electronic Theses and Dissertations by an authorized administrator of ThinkIR: The University of Louisville's Institutional Repository. This title appears here courtesy of the author, who has retained all other copyrights. For more information, please contact thinkir@louisville.edu. 
MORE THAN “MOON GOLD AND MARBLES”: RATIONALIZATION, REFORM, AND

THE TRANSFORMATION OF THE AMERICAN CIRCUS, 1900-1940

\author{
By \\ Matt Holdzkom \\ B.F.A., Pacific Northwest College of Art, 2005
}

\begin{abstract}
A Thesis
Submitted to the Faculty of the

College of Arts and Sciences of the University of Louisville

in Partial Fulfillment of the Requirements
\end{abstract}

for the Degree of

Master of Arts in History

Department of History

University of Louisville

Louisville, Kentucky

May 2015 

MORE THAN “MOON GOLD AND MARBLES”: RATIONALIZATION, REFORM, AND THE TRANSFORMATION OF THE AMERICAN CIRCUS, 1900-1940

\author{
By Matt Holdzkom \\ B.F.A., Pacific Northwest College of Art, 2005
}

A Thesis Approved on

April 20, 2015

By the following Thesis Committee:

Tracy E. K'Meyer

Daniel J. Vivian

Diane Pecknold 


\section{DEDICATION}

This thesis is dedicated to the memory of my mother, Deborah L. Holdzkom, whose words will continue to motivate me to learn all that I can learn,

and

to the memory of Dr. John Hanners, whose work served as a valuable impetus. 


\section{ACKNOWLEDGMENTS}

I would like to thank my advisor, Tracy K'Meyer for her encouragement and advice throughout the process of writing this thesis, as well and Daniel Vivian and Diane Pecknold for serving on my committee. Tremendous thanks also to Louella Hanners, whose diligence and generosity made much of my research possible. Also, thanks to my father, Stephen P. Holdzkom, whose achievements and strength of character continue to shine as a fine example to our family and to the community at large. 


\section{ABSTRACT \\ MORE THAN “MOON GOLD AND MARBLES”: RATIONALIZATION, REFORM, AND THE TRANSFORMATION OF THE AMERICAN CIRCUS, 1900-1940 \\ Matt Holdzkom}

April 20, 2015

The circus, despite its prominence in the American imagination and popular culture, has yet to be given its due among the scholarly studies of cultural historians. This thesis is a historical contextualization of the circus in the United States. It contends that historical processes of rationalization and reform prevalent in the early twentieth century can be adequately interpreted through a study of the circus, and that these forces contributed significantly to the circus' decline in size and cultural relevance in that period. Specifically, this thesis examines the amelioration of corruption and reform of labor relations as instrumental in the shrinkage and decline of circuses in the United States. 


\section{TABLE OF CONTENTS}

PAGE

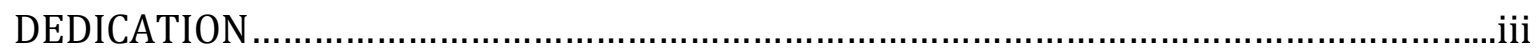

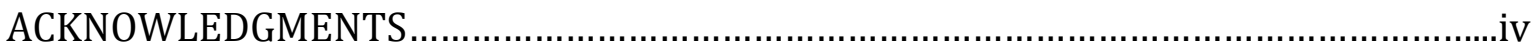

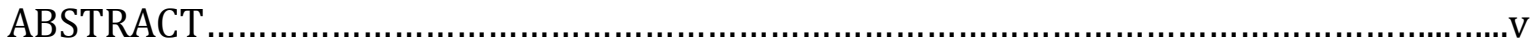

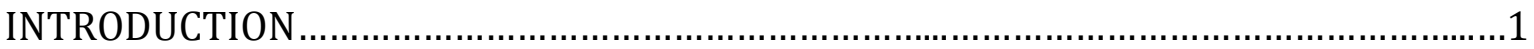

CHAPTER ONE: FORMATION AND ORGANIZATION ............................................14

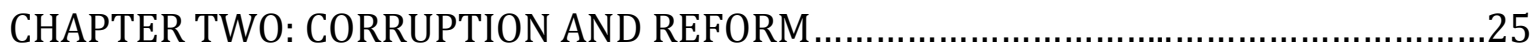

CHAPTER THREE: INDUSTRIAL DEMOCRACY AND THE CIRCUS................................55

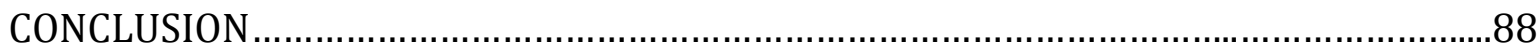

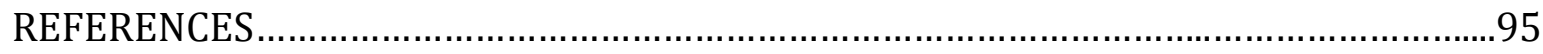

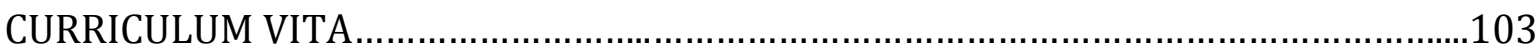




\section{INTRODUCTION}

After a 1938 general strike among the performers and workingmen of

Ringling Brothers and Barnum \& Bailey Circus forced that mammoth enterprise to

limp back to winter quarters five months early, newspapers across the country

published eulogies of this once seemingly indomitable American institution. A

particularly prescient editor in Springfield Massachusetts commiserated,

The circus has folded. To anyone who ever got up before the sun to watch the creaking vans rumble into town or the long gay train pull into the siding that is sad news. We were trained to the inalterable conviction that the circus was a world apart and that circus kings and queens, from the monarch who drove the eight-horse hitch to the glittering empress of the high trapeze, were not as mortals are. In public concept it never was an industry, a business. It was remote from the insistencies of debits and credits and time clocks. It moved in some glamorous orbit of self-sufficiency, its satellites paid off in the coin of adulation. The circus was divorced from the realities of life. Of course, this concept was in a restricted province of thought, a province maintained largely in the wonder of small boys. But some persistent tenor of it has usually carried over to adulthood. The circus is a business, an industry, susceptible to the same defects that trouble other businesses and industries. There is absolutely no reason why it should not be so, even if small boys do think the circus runs on moon gold and marbles. ${ }^{1}$

Today, just as the public largely still considers the circus an innocuous

entertainment running on "moon gold and marbles," historians have largely ignored

it as a topic of scholarly inquiry. In reality, the modern circus is a product of specific historical processes that led to fundamental changes in and the decline of the institution. 
As the nineteenth century was coming to an end, the American circus was at its peak. Conditions were ripe for its ascendancy in the popular imagination, and it grew to a mammoth scale difficult to imagine. It was the perfect embodiment of Gilded Age excess. But by the late 1950s, it had declined dramatically in both size and cultural relevance. By and large, writers on the circus have tended to ignore the transformation and decline of the circus in America, offhandedly attributing it to the rise of easily obtained mass entertainment like television and film. The written history of the American circus, produced largely by hobbyists and circus buffs with a romantic and nostalgic approach, focuses mainly on the performance and equipment, and has always been somewhat divorced from larger patterns in U. S. history. The circle of devotees that produces "circus history," whom I will refer to as the "circus history fraternity," prefers to ignore the attributes of the circus that give it a broader historical significance. The circus has also been largely passed over as a subject of serious inquiry by formally trained historians, despite its magnitude as a cultural force and a substantial corporatized business. In particular, the literature fails to recognize the circus as a victim of the mounting forces being enacted upon it during the progressive era and Great Depression.

This thesis explores the external forces that compelled circus owners to consolidate, simplify, and scale down during the first half of the twentieth century. Alice Ringling, niece of the famous brothers whose circus "would grow apace until it outstripped all competitors," grew up in the midst of the circus winter quarters in Baraboo, Wisconsin. In 1959 she wrote, 
I realize now despite the evidence of sight and sound how fragile our world was. In spite of tents and poles and calliopes and "ponderous pachyderms" ours was only a world of ideas; the ideas formulated only a few short years before in the minds of five venturesome, determined youths. The bringing together of all this heterogeneous treasure from the far corners of the earth to this obscure little farm community in the Baraboo hills was proof of the soundness of those ideas and the determination of those men. If at any time the ideas should fail, or the determination falter, how quickly would the silver wagon be emptied, the big top fall, and our world disappear. ${ }^{2}$

In the reform-minded twentieth century, the "ideas" of Gilded Age circus owners were increasingly challenged. From the regularization of city governments to the establishment of a nationwide standard of living for laborers, the Progressive movement in the United States had direct effects on highly traditionalized circus operations. Through these processes of reform, the circus was irrevocably reshaped.

This thesis contributes to three bodies of literature: histories of the circus, which are overwhelmingly nostalgic rather than scholarly; studies of popular entertainment in the early twentieth century United States, which raise insights about American culture but largely neglect the importance of the circus; and examinations of the expansion of the state and bureaucratic influence on the economy, which do not take into account their effect on entertainment such as the circus. In 1993, theatre historian John Hanners wrote, "No professional historian has written a definitive history of the American circus. At first glance this seems a curious omission given the considerable influence of the circus on American material and popular culture."3 More recently, another historian on popular culture agreed that "Being a vibrant, entertaining, and symbolically loaded aspect of our national heritage and a potentially challenging topic for historians, it is a shame that 
the circus has not ... attracted the interest of formally trained scholars. With few exceptions, the historians of the circus have been circus buffs, people whose nostalgia for the institution looms larger than their penchant for analysis." ${ }^{4}$ And yet another writes, "Despite the circus' centrality to nineteenth-century popular culture, it has received scant attention from historians. [...] Even those works that have taken a broad view of the era's popular amusements tend to ignore the circus." 5

What could account for this apparent gap in the literature? Is the circus indeed too "challenging" a topic? Hanners proposes that "traditional modes of scholarship ... aren't always useful when confronted with the sprawling, complex, and mysterious subculture that constitutes the American circus."6 But having attempted to research the circus, he suggests that the main roadblock is that so much of its primary source material is privately held. Stuart Thayer, one of the biggest names in the circus history fraternity wrote in 1974 that "the controversy as to value is as alive in the realm of circus material as it is anywhere in more scholarly pursuits - the collector versus the student—and whether or not the material itself has any value beyond the information in it..." He added, "the tendency with private collections is to keep them that way, but eventually most material finds its way into an institution and so becomes available for study."7 Indeed, archival organizations with circus collections continue to procure material. Notable examples are the Robert L. Parkinson Library and Research Center in Baraboo, Wisconsin, which is affiliated with Circus World Museum, Milner Library at Illinois State University, and the Hertzberg Circus Collection at the San Antonio Public Library, to name but a few. Traditionally accessed only by hobbyists and amateurs interested in preserving a 
romantic and nostalgic view of the American circus, these collections are useful to the professional historian as banks of raw data, waiting to be interpreted further.

The lack of serious scholarship may also be due to the particular way that the circus has evolved. Now considered a frivolous and innocuous oddity undeserving of scholarly consideration, the circus in the early twentieth century was the most influential and potent popular entertainment available. World's fairs, vaudeville, and other stage shows owe a debt to the success of the circus, and they, in turn, forced it to adapt. Whatever the reason for this gap, in the past ten years the circus has begun to receive attention from scholars operating from without the circus history fraternity. They have uncovered some important historical themes and patterns, but have yet left plenty of opportunities for cultural historians.

Though the new social history began to lend currency to professional studies of commercial entertainment in the 1960s and 1970s, circus history was curiously excluded for decades, even as efforts to preserve, collect, and restore circus artifacts in circus-themed museums was gaining momentum: Circus World Museum in Baraboo, Wisconsin was founded in 1959, the Circus Hall of Fame in Sarasota, Florida in 1956, and the P.T. Barnum Museum opened in Bridgeport, Connecticut in 1968. A historical society had been created in the 1930s "to preserve, promote and share though education, the history and cultural significance of the circus and allied arts, past and present" and was mainly composed of circus fans and antiquarians. The Circus Historical Society's journal Bandwagon was and still is the leading publisher of new circus research. Though Bandwagon articles are generally well researched, they fail to analyze their subjects any further than giving dates and 
names of events of interest to circus buffs. In a sense, Bandwagon articles can be considered "author's archives", or aggregations of primary source material on a certain subject.

Bandwagon articles and book-length histories alike tend to "focus on specific enterprises, performers, owners, or certain aspects of the circus such as clowns, poster art and parades" or on tracing the specific lineage of ownership of a certain circus wagon or group of wagons. ${ }^{8}$ Numerous general histories have been published, notably A History of Circus in America (1959) by George Chindahl and popular histories such as The American Circus: An Illustrated History (1990) by John Culhane. Biographies of P.T. Barnum and his protégé Tom Thumb are innumerable, and more than a few books have been written on the Ringling brothers, especially John Ringling, the last surviving brother, such as Ringling: The Florida Years, 19111930 (1993) by David C. Weeks. Published memoirs of circus owners and performers are also popular, such as The Circus Kings: Our Ringling Family Story (1960) by Henry Ringling North and Alden Hatch, The Big Top: My Forty Years with The Greatest Show on Earth (1952) by equestrian director Fred Bradna and Hartzell Spence, and Spangles, Elephants, Violets \& Me: The Circus Inside Out (2007) by Victoria B. Cristiani Rossi, to name a few.

With very few exceptions, this has been the state of circus scholarship for the past seventy years. As cultural history has progressed from being an outgrowth of intellectual history concerned only with "high" forms of art to an expansive field with a symbiotic relationship with social history, circus historians have not kept up. They have, to borrow the words of cultural historian Karen Halttunen, "uncovered 
mountains of information about the social and material lives of ordinary people in the past" but have failed to become "committed to uncovering the meanings of those experiences." ${ }^{\prime 9}$ However, the truth is that the dearth of serious circus scholarship is now slowly being rectified.

One exception to the rule was an article written by a pair of sociologists in 1972 and published in the Journal of Popular Culture. "Some Perspectives on the Circus in Transition" by Robert C. Sweet and Robert W. Habenstein smashes the conventional approach by skillfully dissecting (in a mere eight pages), the transformation of the American circus from its original identity as hoodwinking foreigner into a community partner-a sponsored entertainment aiding fund raising activities. ${ }^{10}$ The article was an outgrowth of Sweet's Ph.D. dissertation, for which Habenstein acted as advisor. It is not biographical, nor does it focus on any particular group, whether a producer of the entertainment or a consumer. Instead, it discusses changes in society and the "secular trends" which forced the circus to adapt. In this sense it is utterly unique in circus scholarship from the twentieth century. It took thirty years before others engaged in similar investigations.

When Janet Davis' book, The Circus Age: Culture \& Society Under the American Big Top was published in 2002, it was hailed as an ambitious and groundbreaking foray into a topic with much untapped potential. Davis described her work on the circus as "a way to explore then-prevailing attitudes about gender, race, labor, sexuality, monopoly formation, nationalism, and empire."11 The book portrays the turn of the century circus in all of its peculiar details. It introduces a number of sociological aspects of the circus, both in its performance and the atmosphere that it 
created on its daily arrival, and places the circus in an appropriate context of societal change. The Circus Age was perhaps the first book-length, careful study of the American circus by a professional historian that utilized what Halttunen calls "a more holistic concept of 'culture' as the entire range of practices, representations, languages, and beliefs that make up a particular social group's way of life."12 However, faced with its prodigious objective, the book falls short of coming to any defined resolution. As reviewer Robert Bogdan wrote, "the book is more about how prevailing theory provides a script for reading the turn-of-the-century big top circus than about exploring then-prevailing attitudes about race, class, and gender."13 The Circus Age is nevertheless an impressive work, and its themes of gender, race, and imperialism in the circus milieu are important to note.

Building upon Davis' work, Gregory J. Renoff's The Big Tent: The Traveling Circus in Georgia, 1820-1930 (2008) focuses on Circus Day, the unofficial holiday when the everyday activities and transactions of a community ground to a halt and all eyes were on the arrival and presentation of the circus. Though Renoff's focus on circus dates in Georgia may seem unnecessarily selective when studying a form that was uniform in its presentation regardless of location, The Big Tent is also an examination of the community's interaction with the circus. Renoff is interested in exploring the impact of Circus Day and "what it reveals about a community's social, cultural, and economic life." Like Davis, he uses the circus as a lens to view "issues central to southern life, including racial interaction, class formation, religious belief and behavior, popular culture, sectional identity, and the rise of consumerism."14 The southern aspect is an intriguing one, as it provides an oft-neglected perspective 
on popular amusements in general. However, Renoff regularly makes contentious statements with no supporting evidence and shows a definite bias for Georgia-based circuses.

From Barnum \& Bailey to Feld: The Creative Evolution of the Greatest Show on Earth (2014) by Ernest Albrecht is possibly the first study to examine changes within the performances of the largest and most visible of American circuses and the way that audiences received them explicitly. Albrecht follows the Barnum \& Bailey Circus from 1872 to its purchase by the Ringling brothers in 1907 and eventual combination and formation of the Ringling Brothers and Barnum \& Bailey Circus in 1919. He maintains an impressive level of detail in describing the show throughout the twentieth century and up through 2010. In addition, Albrecht discusses changes in advertising, mechanization, and other technological advances that had irreversible effects on the circus, as well as early efforts to preserve a sense of nostalgia. He refers to the show as "an evolving form of popular entertainment meeting changing tastes and cultural shifts." ${ }^{15}$ He does not, however, attempt to link these changes to broader concurrent patterns in U. S. history.

Scholars have given more serious attention to other forms of popular entertainment in the early part of the twentieth century. While these works neglect the importance of the circus, they sketch out the context for it and their insights shed some light on its history. David Nasaw's Going Out: The Rise and Fall of Public Amusements (1993) and Woody Register's The Kid of Coney Island: Fred Thompson and the Rise of American Amusements (2001) discuss the early twentieth century boom in popular amusements. Nasaw in particular shows how disconnected urban 
residents came to "share a common commercial culture" one major development at a time. The circus is easily inserted into this context, since the forms discussed, vaudeville and world's fairs in particular, grew largely out of it. Bruce Lenthall's book Radio's America: The Great Depression and the Rise of Modern Mass Culture (2007) explores the debate over mass culture in the 1930s. In the chapter titled “Radio's Democracy: The Politics of the Fireside," Lenthall describes the growing involvement of national government in daily life during the Depression. Taken as a group, works like these help create a context of coexisting entertainments in a time of swift societal changes. However, the complexity and peculiar size and nature of its workforce makes the circus unique. More than just a form of entertainment or communication, the circus was itself a society. The nature of the travelling circus, composed of numerous individual corps of people, each with a specialized function vital to the overall production and effectiveness of the whole, makes it an ideal vehicle for illustrating the impact of major social processes.

The third body of scholarship to which this thesis contributes is the study of the expansion of the state's role in the economy during the Progressive and New Deal eras. Scholarly studies such as Mark Barenberg's The Political Economy of the Wagner Act: Power, Symbol, and Workplace Cooperation (1993) and George E. Paulsen's book A Living Wage for the Forgotten Man: The Quest for Fair Labor Standards, 1933-1941 (1996) are remarkably detailed works that follow the development, passage, and results of two key pieces of New Deal legislation. While Barenberg's work has a more definitive argument—-that the National Labor Relations Act was "profoundly cooperationist" and intended to encourage collective 
bargaining - the results of the Fair Labor Standards Act are more ambiguous. Nevertheless, these works inform the history of the circus and the changing attitudes of its workforce. In a more general sense, Corruption and Reform: Lessons From America's Economic History (2006) is an invaluable collection of articles presented at a National Bureau of Economic Research conference in 2004. In particular, a paper by John J. Wallis, Price V. Fishback, and Shawn Kantor titled “Politics, Relief, and Reform: Roosevelt's Efforts to Control Corruption and Political Manipulation during the New Deal" demonstrates the extent to which Roosevelt curbed localized corruption to ensure the fair distribution of relief. All of these works have broad implications for the history of the circus.

The circus has existed in the Americas in one form or another since colonial times. Over the past 250 years it has evolved and developed, expanded and contracted, adapted and refashioned itself in countless ways. Likewise, there are innumerable social and cultural aspects to be considered in this, perhaps the most visible of all American entertainment institutions. Janet Davis writes that the circus at its peak "reached virtually all Americans. It educated and challenged people, irrespective of their ability to read or their distance from the metropolis. Its live visual presence made it a popular forum on science, race-thinking, gender ideologies, U.S. foreign relations, and national identity." 16 Its ensuing decline is often speculated about and even dismissed by some who consider the circus alive and well. But as suggested by Sweet and Habenstein, "the developments of rationality, technology, and bureaucracy" in the first half of the twentieth century "found vulnerable an institution which was by its very nature both deeply rooted in 
but existing on the periphery of American culture."17 I hope to expand upon this thesis by exploring the specific forces that were applied to the circus by the enlarging state and the reactions of major circus purveyors. Rather than focusing on the content of the circus performance, I am mostly concerned with the structure of the circus as an institution and the social and labor relations therein. In short, pressures during the so-called progressive era that are very much a part of our national history disrupted the traditional internal order of the circus, bringing its golden age to an end. I plan to rejoin these two threads of the state and the circus in order to expose what I see as a more accurate and inevitable history of the circus in the United States from 1900 to 1940 and to discover how and why it reshaped itself from a gritty and "symbolically loaded aspect of our national heritage" into what we now know as an innocuous form of sanctioned family entertainment.

In chapter one I outline the formation and organization of the railroad circus in the second half of the nineteenth century and liken it to other industries that flourished in the Gilded Age. Chapter one functions as a foundation and starting point for following chapters, while chapters two and three form the core of my argument. Chapter two explores the relationship between the corrupt city governments of the early twentieth century and the shortchanging and gambling that frequently occurred on circus lots. It follows the subsequent efforts of urban reform and describes the impact of that reform on circuses. In chapter three, I follow a similar tack in discussing the effects of labor reform. With chapter four I conclude that these efforts of reform hampered the organizational structure of the circus, causing its transformation and accelerating its decline. 
1 "Excerpts From Editorials and Letters Regarding Ringling-Barnum Closing" Billboard, July 9, 1938, p. 63.

2 C. P. Fox, A Ticket to the Circus: A Pictorial History of the Incredible Ringlings (New York: Bramhall House, 1959), 17.

3 John Hanners, "It Was Play or Starve": Acting in the Nineteenth Century American Popular Theatre (Bowling Green: Bowling Green State University Popular Press, 1993), p. 131.

4 Robert Bogdan. Review of The Circus Age: Culture and Society Under the American Big Top by Janet M. Davis, The American Historical Review, June 2003.

5 Gregory J. Renoff, The Big Tent: The Traveling Circus in Georgia, 1820-1930 (Athens: University of Georgia Press, 2008), pp. 2-3.

6 Hanners, 131.

7 Stuart Thayer, "One Sheet" Bandwagon, Vol. 18, No. 2 (Mar-Apr), 1974, p. 17.

Accessed July 30, 2014 at http://circushistory.org/Bandwagon/bw-1974Mar.htm

8 Judith A. Adams-Volpe, "Circus and Wild West Exhibition" in The Greenwood Guide to American

Popular Culture, eds. M. Thomas Inge and Dennis Hall (Westport, CT: Greenwood Press, 2002), p. 257.

9 Karen Halttunen, introduction to A Companion to American Cultural History, ed. Karen Halttunen

(Malden, MA: John Wiley \& Sons Ltd., 2014), xi.

10 Robert C. Sweet and Robert W. Habenstein, "Some Perspectives on the Circus in Transition" The Journal of Popular Culture, Spring 1973, No. 3, p. 587.

11 Janet M. Davis, The Circus Age: Culture and Society Under the American Big Top (Chapel Hill: The University of North Carolina Press, 2002), xiii.

12 Halttunen, Companion to American Cultural History, xi.

13 Bogdan, Review of Davis, Circus Age, 833.

14 Renoff, The Big Tent, 3.

15 Ernest Albrecht, From Barnum \& Bailey to Feld: The Creative Evolution of the Greatest Show on Earth (Jefferson, NC: McFarland \& Co., Inc., 2014), 4.

16 Davis, Circus Age, 13.

17 Sweet and Habenstein, "Some Perspectives..." 583. 


\section{CHAPTER ONE: \\ FORMATION AND ORGANIZATION OF THE \\ AMERICAN RAILROAD CIRCUS}

When the circus was established in this country, it was not a traveling enterprise. In the late eighteenth century, semi-permanent wooden structures were built in eastern cities to exhibit equestrian displays and acrobatics during the summer months. Sometime before 1772, English equestrian and former sergeant major Philip Astley had found that a horse cantering in a circle of a certain size at a constant speed would create enough centrifugal force that he could stand comfortably upon its back. Over time, Astley invented riding tricks, and he and his compatriots became well known in Britain and France for their skill and daring in the 1770s. ${ }^{1}$ Another Englishman, John Bill Ricketts, popularized the form in the United States after establishing a similar riding school in Philadelphia in 1792. Equestrian shows of this type increasingly included acrobatics, singers, puppet shows, and other "histrionic elements, especially such as afforded opportunity for the use of horses." 2 These shows consisted of a series of acts performing in succession within a single ring. At this time, "circus" referred to the structures under which the performance took place.

By the 1820s, performances of this type began to incorporate menageries of exotic animals. Scattered occurrences of various species on display in the colonies reach back to the early 1700 s, with the first lion exhibited in 1716 . By the 1790 s 
assemblages of animals from Africa and Asia were well established, and the first elephant arrived on American shores in $1796 .^{3}$ With the assimilation of menageries, circuses procured an educational rationale, and enjoyed a diverse patronage at a time when "amusements" were considered thoroughly "lowbrow."

In 1825, circus owner Joshua Purdy Brown was the first to produce such a show under a canvas "pavilion," which allowed him to take his show anywhere he could find an audience. This mobility opened western markets but also required an increase in equipment, logistics, and capital. At the same time, traveling menageries criss-crossed the countryside exhibiting strange beasts for the edification of the public. These two amusements began to merge in the 1830s to form the core of what we know as the American circus. These traveling exhibitions of trick riders, acrobats, wire walkers, clowns, and exotic animals were the so-called "mud shows," trudging with heavy hooves over the country's undeveloped roads in spindlywheeled wagons.

The American circus acquired its distinctive flash and proportions after the rise of the railroad. As early as 1850 , some determined showmen travelled by rail, which required a force of manual laborers to haul equipment from the rail yard to the show ground by hand. These "gilley shows" were often smaller than the overland shows and were therefore unpopular with audiences. ${ }^{5}$ However, an innovation in 1872 revolutionized the traveling circus. Circus owner W.C. Coup originated the idea of railroad flatcars custom-made for circus conveyance. Not only were they twice as long as standard flatcars, they also included connecting "crossover plates" so that wagons could be pulled from one car to the next by a team 
of horses on the ground alongside. The last car of the string had long ramps (or "runs") to allow the wagons to be unloaded from the train and taken directly to the show ground. This "piggybacking" method along with the expanding network of railroads throughout the country sparked explosive growth in the circus industry. The railroad circus increasingly required large-scale industrial organization and substantial manpower. With these innovations came the golden age of the American circus.

The circus was the epitome of Gilded Age bigness. As industry boomed under an abundance of raw materials and finance capital and government's laissez-faire attitude toward business, the circus business did likewise. ${ }^{6}$ After taking to the rails, circus managers were relatively unimpeded by former restrictions of weight and quantity of wagons, and they filled car after car with ostentatious wagons, props, animals, performers, workers, and bombast. Coup and his partner P. T. Barnum entered into competition with the circus of James A. Bailey, each continually oneupping the number of wagons the other reported in its parade. In 1881, these two circuses merged into one giant show, Barnum \& Bailey's "Greatest Show on Earth" and boasted three rings of continuous action. ${ }^{7}$ By the 1890s, the circus of five enterprising brothers named Ringling was challenging Barnum \& Bailey's for superiority in the field of circus gigantism.

In 1890, the Barnum \& Bailey big top measured 460 feet in length. In 1903, the Ringling Brothers Circus traveled on sixty-five train cars. By 1910, each of these massive shows required eighty-four cars, while several others used over forty. ${ }^{8}$ Their cavernous main tents ("big tops") could accommodate upwards of ten 
thousand spectators at a time. The American circus was enjoying its heyday. By 1903, there were ninety-eight privately owned combined circuses and menageries traversing the United States, occasionally playing to crowds in Mexico and Canada. ${ }^{9}$

At the turn of the century, in many communities Circus Day became an unofficial holiday anticipated as much as Christmas day or the last day of school. ${ }^{10}$ From pre-dawn until late at night, the dynamic and commanding presence of the circus dominated the day. The American railroad circus brought a captivating, worldly city of amusement and amazement to communities across the continent and then whoosh-vanished the following day. The novelist and poet Hamlin Garland wrote in 1899, "To go from the lonely prairie or the dusty corn-field and come faceto-face with the 'amazing aggregation of world-wide wonders' was like enduring the visions of the Apocalypse." "The tumult was benumbing."11

Not only did the circus bring dazzling entertainment to the public, it also brought an urbane class of confidence men and swindlers. Professional and amateur criminals alike looked to exploit the carnivalesque atmosphere and great crowds of Circus Day. While some operated independently, others were employed by the circus to lighten the pocketbooks of disoriented circus-goers. Short changers moved through the crowds engaging customers of means, deftly fleecing them of a dollar here, a dollar there. Equally skilled practitioners of gambling games like three card monte dumbfounded circus-goers by winning their money at will. The profits of these "grifters" or "lucky boys" were a traditional source of revenue for circus owners-one that kept many shows financially sound. For that reason, circus grifters occupied a prominent place in the circus hierarchy, some becoming circus 
managers themselves. But the corruption that came with the circus was unwelcome by the town, and local newspapers often advised extra vigilance on Circus Day.

Nineteenth century showmen like James A. Bailey, Adam Forepaugh, and P. T. Barnum had much in common with the magnates of the huge steel and oil trusts. Their circuses developed in a time when the right of employers to accumulate unlimited wealth eclipsed the right of employees to enjoy a comfortable living. ${ }^{12}$ Circus owners, like industrialists, believed that prosperity was achieved through the qualities of exceptional individuals. Their professional histories read like the ubiquitous novels of Horatio Alger. Furthermore, they believed in concentration over competition; circus history is strewn with mergers, buy-outs, and combinations. Opposition required costly advertisements and large circuses preferred to absorb competitors rather than endure their badgering. After the deaths of P. T. Barnum and James Bailey, the Ringling brothers purchased that famous circus in 1907. They were combined after World War One to form the Ringling Bros. and Barnum \& Bailey Circus that audiences know today.

Circuses also embodied Gilded Age industrial organization. Railroad circuses varied in scale, but the average show could be moved on about thirty cars. Regardless of size, they were uniform in their systematization. The trains were organized in different sections, each arriving in the order it was required on the lot. For example, those cars containing the dining department and the canvas department might travel on a different section than those of the property department since the cookhouse and tents were needed before rigging and other equipment. Performers were among the last to arrive. Unlike other forms of 
popular amusement that came into prominence at this time such as vaudeville, the circus required large numbers of manual laborers in addition to skilled performers.

Manual laborers on the circus fell into one of numerous departmental categories designed for systematic efficiency. The following tables list the various positions within each department and illustrate the complexity of circus logistics during the 1920s and 30s. ${ }^{13}$ Not included are the circus owner, general manager, assistant manager, treasurer, and bookkeeper, who naturally hold the highest positions. Legal adjusters and grifters have also been omitted (the former being responsible for arranging protection for the latter), but they would also be classed among the elite, since they performed such a vital role. In some cases, the assistant manager was also the legal adjuster. The equestrian director presided over performers, and the general superintendent over workingmen.

\section{Table 1: White Collar Staff}

\begin{tabular}{|l|l|}
\hline Advance Department & $\begin{array}{l}\text { General agent, Contracting agents, 24 hour men, } \\
\text { Advance car managers, Banner squarers, Banner } \\
\text { tackers, Billposters, Paste cook, Lithographers, } \\
\text { Programmers, Banner checkers }\end{array}$ \\
\hline Candy Stands & $\begin{array}{l}\text { Superintendent of concessions, Concessions } \\
\text { assistant, Cashier, Stock man, Candy floss man, } \\
\text { Hamburger sellers, Lemonade sellers, Outside } \\
\text { candy sellers, Novelty sellers, Popcorn sellers, } \\
\text { Porter, Inside sellers, Bug men }\end{array}$ \\
\hline Front Door & $\begin{array}{l}\text { Front door superintendent, Exchange desk man, } \\
\text { Ticket takers, Tax collector }\end{array}$ \\
\hline Side Show & $\begin{array}{l}\text { Side show manager, Assistant manager, Lecturer, } \\
\text { Ticket sellers, Ticket takers }\end{array}$ \\
\hline Ticket Department & $\begin{array}{l}\text { Superintendent of tickets, Connection ticket } \\
\text { seller, Downtown ticket seller, Menagerie box } \\
\text { ticket seller, Track box ticket seller, Reserved } \\
\text { seat ticket seller }\end{array}$ \\
\hline Usher department & Head usher, Gatemen, Ushers \\
\hline Press department & Contracting press agent, Story men \\
\hline
\end{tabular}


Table 2: Manual Laborers

\begin{tabular}{|l|l|}
\hline Canvas department & $\begin{array}{l}\text { Big top superintendent, Assistant } \\
\text { superintendent, Canvasmen, Pole riggers, Seat } \\
\text { men, Seat carpenter, Stake and chain wagon man, } \\
\text { Stake driver machine men, Donniker man, } \\
\text { Sideshow boss canvasman, Sideshow canvasmen }\end{array}$ \\
\hline Dining department & $\begin{array}{l}\text { Steward, Head waiters, Bread boy, Boiler wagon } \\
\text { fireman, Butcher, Coffee boy, Chefs, Cooks, } \\
\text { Waiters }\end{array}$ \\
\hline Baggage stock department & $\begin{array}{l}\text { Superintendent of baggage stock, Assistant boss } \\
\text { hostler, Drivers, Helpers, Feed man }\end{array}$ \\
\hline Blacksmith shop & $\begin{array}{l}\text { Boss blacksmith, Blacksmith helper, Carpenter, } \\
\text { Horse shoers, Lead bar detective, Painter, } \\
\text { Harness maker }\end{array}$ \\
\hline Elephants & $\begin{array}{l}\text { Superintendent of elephants, Assistant boss bull } \\
\text { man, Front bull hands, Back bull hands }\end{array}$ \\
\hline Menagerie department & $\begin{array}{l}\text { Superintendent of menagerie, Assistant boss of } \\
\text { menagerie, Cage hands, Camel punks, Giraffe } \\
\text { man, Zebra boys }\end{array}$ \\
\hline Light department & Superintendent of lights, Assistant, Helpers \\
\hline Property department & $\begin{array}{l}\text { Superintendent of properties, Assistant boss } \\
\text { property men, Property men, Riggers }\end{array}$ \\
\hline Ring stock department & $\begin{array}{l}\text { Superintendent of ring stock, Ring stock } \\
\text { assistant, Grooms, Pony punks, Dog boys }\end{array}$ \\
\hline Sleeping cars & $\begin{array}{l}\text { Boss porter, porters, honey bucket man, Big pie } \\
\text { car manager, Pie car cook, Pie car counter men, } \\
\text { Working man's pie car attendant } \\
\text { Miscellaneous }\end{array}$ \\
\hline Traperintendent of tractors, Drivers, Helpers \\
\hline Train department & $\begin{array}{l}\text { Trainmaster, Assistant trainmaster, Cable boy, } \\
\text { Car knocker, Chockers, Night watchman, Hook } \\
\text { rope boys, Deck polers, Chute poler, Wheelers, } \\
\text { Snubber, Electrician }\end{array}$ \\
\hline $\begin{array}{l}\text { Announcer, Bandmaster, Band men, Calliope } \\
\text { fireman, Calliope player, Show doctor, Horse } \\
\text { trainers, Ice man }\end{array}$ \\
\hline
\end{tabular}

In general, the makeup of the unskilled workforce on any circus, such as

canvasmen (who could number in the hundreds) and the lower positions in the

train crew was fluid and diverse. Senior workers ("bosses") were Euroamerican

males and remained in their positions for the extent of their careers, perhaps

exchanging employment with one circus for another if a more desirable situation

arose. Unskilled laborers came and went, relatively unhampered by management. 
In some cases the circus might "hold back" a portion of a workman's pay for a period of time- - a technique ostensibly intended to regulate turnover. However, undoubtedly there were many instances of holdback pay that was never claimed by transient workers, the end result being a significant savings by management. Hiring practices varied according to the customs of the manager. James A. Bailey was notorious for his refusal to hire black workers, while the Sells Brothers Circus, based in Ohio, did so regularly. ${ }^{14}$ By and large, circuses hired whatever help was readily available. One trouper notes that circuses were particularly reliant on black laborers while touring the South. ${ }^{15}$

While the main circus band that performed under the big top during the performance was all white, African American bandsmen made up the sideshow band. These sideshow bands played a significant role in the early development of jazz-particularly that of Prof. P. G. Lowery, who led a band of black musicians in various circus sideshows for over twenty-five years. ${ }^{16}$

As for performers, a caste system similar to that of the legitimate theatre was observed. The equestrian director acted as stage manager and master of ceremonies, facilitated relations among the hundreds of performers from all points of the globe, and kept the circus performance running smoothly. ${ }^{17}$ Star performers enjoyed such privileges as private dressing rooms and exemption from added chores. Clowns occupied the bottom rung of the social ladder along with ballet girls, who were hired from the theatre every year to pad the grandiose look of the performance. 
With such a complex, self-contained, and time-sensitive operation, a strict hierarchy was required of the staff to maintain order. The managers, performers, and workingmen all occupied separate spheres, and within those spheres existed various levels. Star performers, for example, would not have associated with ballet girls. In the cookhouse, where employees ate their meals, a dividing "wall" of canvas separated performers from workers, and tables were assigned by department, act, and race. Likewise, sleeping arrangements on the train were determined by social position. Owners and star performers enjoyed exclusive and well-furnished Pullman cars, while workingmen occupied wooden bunks stacked three high, and often infested with bedbugs and lice. ${ }^{18}$ Performing couples or families had similar bunks unless they were feature acts, and single women occupied a separate car, sometimes dubbed the "virgin's car." Caste dictated the layout of dressing rooms for performers, too. Each performer's trunk was spotted in the same place every day according to rank. Tiny Kline, who performed a minor role in the Barnum \& Bailey Circus, wrote, "Indeed, the place of your trunk determined who you were." "[T]hose whose trunks were placed against the outer wall were at a terrific disadvantage. They suffered greatly from lack of privacy, [...] but particularly from the weather, being exposed to the elements of wind and rain from over and under the sidewall."19

Regardless of the weather or any other environmental forces, the circus moved from town to town from April to November, giving two performances per day, resting only on Sunday. Through rain and mud, windstorms and heat, train crashes, derailments, and fires, boom and bust, the entire company lived by the circus maxim, "the show must go on." At the end of the season, the show returned to 
its winter quarters-often the hometown of the owner-where it hibernated until after Christmas. Performers found work in vaudeville or other indoor venues, and the workingmen not retained to care for the animals over the winter looked for work in various industries or lived "on the bum." By February, acts were being contracted and might be in training at winter quarters. New canvas was purchased and the "sailmakers" built the requisite ten or more tents (always called "tops"), which were then treated with a fire retardant solution. The managers made decisions about the route and composition of the show and the necessary equipment was refurbished. Each wagon, railroad car, seat, pole, and prop was given a fresh coat of paint. In the spring, the circus opened the new season by playing a stand for its host city before loading onto the train and embarking on the tour.

The American circus was incubated in the Gilded Age and it grew into a powerful and rugged cultural force in the twentieth century. Though mergers were common, rival circuses still battled fiercely all over the country. Performers with stupefying skills from across the globe, weather-beaten laborers, and cunning confidence men made the circus their home. Throngs of spectators packed circus lots to witness this spectacle of flamboyantly presented performance as well as the utilitarian, pre-industrial force of men and horses that built and dismantled the canvas city day after day. The locomotive had made it all possible; but the underlying mechanisms that perpetuated such a grand enterprise were political corruption and cheap labor. 
1 John Culhane, The American Circus (New York: Henry Holt \& Co., 1990), 1-2.

2 George L. Chindahl, A History of the Circus in America (Caldwell, Idaho: Caxton Printers, Ltd., 1959), 192.

3 Ibid., 2, 17.

4 For more on the early American culture wars, see Lawrence W. Levine, Highbrow Lowbrow: The Emergence of Cultural Hierarchy in America (Cambridge, MA: Harvard University Press, 1988)

5 Janet M. Davis, The Circus Age: Culture \& Society Under the American Big Top (Chapel Hill: University of North Carolina Press, 2002), 19-20.

6 Michael McGerr, A Fierce Discontent: The Rise and Fall of the Progressive Movement in America, 1870-1920 (New York: Oxford University Press, 2003), 150.

7 Davis, Circus Age, 21.

8 Chindahl, History of the Circus, 150.

9 Davis, Circus Age, 7.

10 Bert J. Chipman, Hey Rube! (Bert J. Chipman, 1933), 60.

11 Robert M. Lewis, ed., From Traveling Show to Vaudeville: Theatrical Spectacle in America, 18301910 (Baltimore: Johns Hopkins University Press, 2003), 147, 148.

12 Paul Krause, The Battle For Homestead, 1880-1892: Politics, Culture, and Steel (Pittsburgh: University of Pittsburgh Press, 1992), 6.

13 Tables from Joe McKennon, Logistics of the American Circus (Sarasota: Carnival Publishers, 1977), 8-10.

14 Davis, Circus Age, 70.

15 Chipman, Hey Rube, 136.

16 For more on this, see Lynn Abbott and Doug Seroff, Ragged but Right: Black Traveling Shows, "Coon Songs," and the Dark Pathway to Blues and Jazz (Jackson, MS: University Press of Mississippi, 2007).

17 Fred Bradna and Hartzell Spence, The Big Top: My Forty Years with The Greatest Show on Earth (New York: Simon and Schuster, 1952), 101-2.

18 George A. Hamid, Jr. Circus (New York: Sterling), 51.

19 Tiny Kline, Circus Queen and Tinker Bell: The Memoir of Tiny Kline, ed. Janet M. Davis (Urbana: University of Illinois Press, 2008), 118-9. 


\section{CHAPTER TWO \\ CIRCUS GRIFT IN THE EARLY TWENTIETH CENTURY: CORRUPTION AND REFORM}

The period known as the "Gilded Age" acquired its name from an 1873 novel by Mark Twain and Charles Dudley Warner about "grifters and grafters gone amuck." ${ }^{1}$ As much as the circus business resembled the giant trusts of the robber barons, it was also infected by the pervasive corruption of the age. Despite the conventional wisdom that political corruption stifles economic growth, American cities blossomed under notoriously corrupt leadership between 1880 and 1930. A 2006 essay by economics professor Rebecca Menes examines the "opportunistic infection" of corruption and illustrates how corrupt local officials managed to hold the favor of their constituencies by providing essential services while lining their own pockets. ${ }^{2}$ In this case, corruption, which she defines as "misuse of public power for private purposes," led to flourishing cities. ${ }^{3}$ But as Progressive ideas seized the minds of the urban middle class, corruption in city government came under attack. The pattern of corruption and reform in U.S. cities corresponds directly with the practice of grift common on circuses in the late nineteenth and early twentieth centuries.

A modification of the word "graft," grift means, "to engage in petty swindling." In the circus world, grift included the "crooked games, short change 
artists, [...] merchandise boosters, pickpockets and all other types of skullduggery $\left[\right.$ sic] ${ }^{\prime 4}$ carried to varying degrees by most circuses around the turn of the twentieth century. These practices provided a vital source of income for circus owners; one experienced con man estimated that up to 80 percent of circus profits stemmed from grift. ${ }^{5}$ Impossible—or at least impractical—without the support of corrupt city officials, the prevalence of circus grift reflected the urban conditions of the era, and thus lends valuable insights into the relationship between the circus and the rest of society. These practices, along with their eventual abolishment, demonstrate the early twentieth century progressive struggle for reform and the increasing bureaucratization of society that resulted. Through various efforts to clean up corruption and regularize business practices, the circus was transformed from an adversarial outside force into a cooperative and innocuous community partner.

By the turn of the century, a system of government that had germinated in small communities had sprouted crooked and misshapen in the ever-expanding cities. Rapid urban growth forced city officials to search for ways to provide an increasing variety of essential goods and services. ${ }^{6}$ With few regularized systems for determining who would get such contracts, officials were tempted to take advantage of their position. Reigning administrations handed jobs and contracts to business partners and political supporters, leading to ineffective and wasteful services.

Similarly, no federal power existed to orchestrate a sensible order. In the words of historian Robert H. Wiebe, the United States was "a society without a core."7 In the late nineteenth century, "[n]o one expected great men in politics." 
"Lawmakers by the score came to expect cash and whiskey as their due," and "anyone who watched knew and so few cared." 8 Muckraking journalists exposed the bribery, kickbacks, insider trading, and criminal cover-ups common around the turn of the century, but these improprieties failed to ignite public indignation, much less action.

Despite rampant corruption, the pushing masses continued to flow into urban centers while city bosses struggled to keep up. Economist Rebecca Menes illustrates how corruption was mutually beneficial for both parties through the example of urban streetcar lines. Responding to public demand, local bosses "manipulated the price of common stock, set up construction firms to build the streetcar rails and overpaid themselves, and speculated in real estate along the streetcar lines." As a result, extensive streetcar lines were quickly built. This system of graft was mutually beneficial to both the bosses and the voting public, which meant that corrupt administrations tended to remain in power. It also led to spectacular growth in comparison to streetcar systems in Europe, where owners were forbidden to speculate on bordering real estate. ${ }^{9}$

Similarly, corruption around the circus benefitted city bosses and circus managers. From the perspective of circus managers, circus grift became a compensatory reaction to the corrupt system of political machines and their bosses. Before authorizing the necessary licenses and permits to exhibit in a town, local officials sometimes extorted exorbitant fees from the applicant. Consequentially, circuses, carnivals, and fairs engaged in grift to recover their losses. ${ }^{10}$ In the case of circuses, city and county officials often required large numbers of complimentary 
tickets, occupying all the best seats. ${ }^{11}$ In exchange, the bosses turned their heads, allowing circus confidence men to swindle the public, and guaranteeing their protection from arrest. "Shakedowns," a form of extortion in which local officials fabricated charges against a circus employee were also common. In order to avoid the delay of future court appearances, the circus was obliged to make under-thetable payments. ${ }^{12}$

Newspapermen also took advantage of the arrival of the circus. In many towns, circus press agents found that they were charged a higher advertising rate than local businesses. In some cases, newspaper managers also required steep minimums in order to print circus advertisements. ${ }^{13}$ Additional tickets were given out to newspaper staff and their families. By the end of the twenties, the "circus pass evil" had grown to include requests from railroad employees, lot owners, and firemen in addition to the mayor and police departments. ${ }^{14}$ Each of these departments provided a service to the circus and expected recompense. Even prior to its arrival, the circus was vulnerable to the forces in power at a locality. The sense of antagonism was heightened after circus grifters had "fleeced" the town.

The predation of circus patrons began from the moment a ticket was purchased. In a newspaper article published in 1930, circus veteran Vernon Reaver described one method of a grifting circuses to flag ideal targets.

The way the graft was worked in the old days was for the ticket seller at the main entrance to size up a man's bankroll. If it was a little one, the ticket agent paid no attention to that particular man. But if the roll was a big one he would say: "I take it, my good friend, that you want to go all the way through [the menagerie as well as the main performance]." Then he'd lean over and stick a ticket, like a railway conductor's ticket, in the man's hatband. There were different color tickets which indicated the amount of money the ticket seller 
estimated was in the man's purse-a red ticket announced that the man had about $\$ 100$, a blue ticket indicated $\$ 50$. This ticket in the man's hatband told every employee of the circus that the man had money and was a desirable person to steal from. Scores of tricks were played to get his money. ${ }^{15}$

The fundamental practices of grift were flat joints and shortchanging. Various ancillary practices are sometimes grouped into the term, including strip teases (called "cooch" shows) that sometimes took place in the sideshow tent, and pickpocketing (or "dip"). Strictly speaking, true circus grifters professed that they never took anything that was not handed to them by their selected victim (or "mark"). That is the pride of the confidence man. But in the protected domain of the circus, grifters had free reign. Ultimately, the entire circus milieu had been set up to fleece marks.

Flat joints were seemingly simple games in which the mark had no chance of winning due to the skill of the grifter. Some of the most common games were the shell game and three card monte. These games were set up on small tripod stands in the sideshow tent or occasionally in a small tent designated for the purpose called the "G" top.

In the shell game, a dealer manipulates three shells or small wooden boxes and a pea-sized ball of soft rubber. The dealer is highly skilled in transferring the "pea" from one shell to another in such a way that is undetectable to the mark. Alternately he may slip the pea out from the shells unobserved, keeping it hidden pressed between two fingers.

In addition to the deftness of the grifter, the mark is vulnerable to an artificial environment created to make him feel that he can win. This is one reason that grift 
on the circus was so successful. The entire setting was fabricated and controlled by the circus. Assisting the dealer are an outside man, who lures marks into the game, half a dozen boosters (also called "shills"), who are ordinary patrons of the circus, and the booster handler, who collected the boosters from the show grounds. The outside man acted as a fellow gambler and an ally to the mark, while boosters disguised the true object of the game, since the mark may recognize them as neighbors and feel secure in joining. ${ }^{16}$ Boosters were allowed to win small amounts to encourage the mark to play. Through methods like these, the grifter creates a false world in which he controls the outcome. David W. Maurer, professor of linguistics and an expert in confidence men, wrote, "like the spectator regarding the life groups in a museum of natural history, [the mark] cannot tell where the real scene merges into the background."17

When the game begins, the dealer places the "pea" under one shell and moves them slowly around the board. The booster handler gives the boosters money to bet on the location of the pea, and they win easily. In the next round, the dealer makes a "crude move" with the shells, transferring the pea into another shell, but this time the booster loses. If the mark detected the move, he is drawn into the game. The mark has observed the game up to this point and believes he can win, when in reality the dealer is in total control of the outcome. The dealer has the option of letting the mark win occasionally in order to extend the game and increase the stakes in a technique called "faro banking."18

Three card monte is a similar game in which one queen and two other playing cards are laid face down on the table. The objective of the game is simply to 
find the queen. Just as in the shell game, the outside man may appear as a friend to the mark, finding a way of folding the corner of the queen to make it ostensibly simple to find. Through sleight of hand, the dealer or the outside man replaces the queen with another marked card and the mark loses. ${ }^{19}$

Grifters employed various methods of short changing, but most begin with a some kind of request for a courtesy, and end with sleight of hand. Many shortchangers started as vendors ("candy butchers") on the circus or at railroad depots. Candy butchers sold candy, juice, and other small concessions and learned how to cheat customers out of small change here and there.20 "The candy seller would show you 90 cents in change that was rightly coming to you. But when he turned it over into your hand he'd hold a quarter in his palm. ${ }^{21}$

Shortchangers on a grifting circus could be found the moment a patron set foot on the circus lot, stationed on the perimeter of the grounds with bundles of tickets shouting, "Reserved seats to the big show, ladies and gentlemen! Better buy them now, or you may not have a chance on the grounds. Only a few of the best seats left." After hastily purchasing a ticket, the patron would be short "most of the change he had proffered in payment for the tickets. Perhaps he never woke up to his loss, but thrust his change into his pocket, without counting. Or, if he did wake up, maybe he did not have the nerve to go back and protest."22 Alternately, shortchanging in paper money frequently occurred in the canvas passage between the menagerie top and the big top. Consequently it was commonly referred to as the "connection." One method involved asking a mark to exchange paper money for coins. The mark hands the grifter a five or ten dollar bill, which the grifter promptly 
folds into a small square. He then begins counting out nickels in exchange. When the mark objects to so much small change, the grifter seems to concede and relinquish the bill, but actually passes him a similarly folded one dollar bill he had been palming in his hand. ${ }^{23}$ Several variations of this trick exist, each with its own name. A good shortchange artist could make several hundred dollars a day with techniques like these. While touring Canada during World War One, a shortchanger with the Hagenbeck-Wallace Circus named Chester Monahan supposedly took $\$ 2,300$ in one day during World War I. ${ }^{24}$

Finally, the "walk away" was another method of shortchanging customers. In the crush of impatient and enthusiastic customers, ticket sellers worked as quickly as possible. With deft fingers and calculations, ticket sellers sitting in the elevated ticket wagon placed a customer's change on the countertop sill of the high ticket window, usually above the customer's line of sight. Anything that was not immediately claimed was swiped onto the floor of the wagon as the next patron was served. Alternately, the change could fall onto the ground, where a mat hidden in the dirt caught it, to be shaken out later. Any complaints were directed to the legal adjuster.

Grifting shows employed legal adjusters (most often referred to as fixers), who worked with corrupt local officials to secure protection for the circus and also dealt with any complaints arising from disgruntled customers. Early in the morning on Circus Day, the fixer visited a saloon or pool hall where illegal gambling took place. Here he was able to ascertain the condition of the town, level of corruption, and the name and whereabouts of the man to speak to in order to secure 
protection..$^{25}$ One experienced fixer reported, "Armed with the right information from the man behind the bar, I sought out the political power in the community. There was always such a power, for local politics are alike everywhere in this country. Perhaps he was the Mayor, or maybe he was a Congressman." ${ }^{26}$ Good fixers belonged to several fraternal clubs and organizations-Elks, Masons, Odd Fellows, etc.-as a way to appeal to the boss in the city or town. Glenn Wakefield, a grifter who went by the pseudonym "Ham Bannister" remarked, "I've seen some of them with more pins on them than Napoleon Bonaparte."27 Once located, officials were "fixed" using free tickets, "drinks, dinners, cigars, or anything money can buy." ${ }^{28}$ After meeting with officials, the fixer specified the level of grift that he felt was appropriate. "He can tell how things stand when he gets through talking to them, and will work accordingly."29 The fixer ensured that the grifters would be safe within the confines of the circus.

The fixer may also be required to smooth out any difficulties arising from illadvised law enforcement. An account of a "tin star marshall mustered in for circus day service" published in 1933 illustrates the practicality of the legal adjuster as well as the dichotomy of principles within an early twentieth century town government. Though the town had been "fixed" with one official, evidently another had sent deputies to the circus lot. Upon finding shell games occurring in the sideshow tent, the deputy excitedly reported to the circus manager. "Men with little tables?" asked the manager. "Darn those fellows, they told me they were amateur photographers and wanted to take some pictures." The deputy was delegated to the legal adjuster and "did not venture near the sideshow during the rest of the day." 30 
Interestingly, many of the most successful grifters hailed from the state of Indiana. When asked why this might be, one con man replied, "It's an old saying among grifters that any Hoosier farmer would come up to you and ask you where the squeeze (controlling device) was on your joint, and then show you that he had figured out a better one. So I guess the farmer boys thought flat-jointing was better than looking at a horse's tail all day for about a buck."31

Though not all circuses carried grift (and those that did used it to widely varying degrees), the largest and most prominent of those that did were those of the American Circus Corporation (ACC). Ultimately a conglomeration of six major circus titles, Ed Ballard, Jerry Mugivan, and Bert Bowers owned and operated the ACC throughout the 1920s. The corporation made its winter home in Peru, Indiana, where Benjamin Wallace had founded its most prominent circus, HagenbeckWallace, in 1884. Wallace, Ballard, and Mugivan all made great profits from circus grift before liquidating their circus holdings.

Benjamin E. Wallace (1847-1921), affectionately known as "Uncle Ben" to the inhabitants of Peru, began his professional life as the owner of a livery stable, which he bought with the bounty he received for enlisting in the Union Army. ${ }^{32}$ Wallace was known as a peerless judge of horseflesh, and his stock was always exemplary. Perhaps suggestive of the acumen that would make Wallace a successful-if somewhat unscrupulous—businessman, a contemporary described Wallace as "a man possessed of that magnetic individuality, which always characterizes a man 'born to be a leader among men.' Introduced to him you feel the hearty clasp of a warm hand, and are made the recipient of a frank, hearty greeting, but all the time a 
pair of half-piercing, half smiling eyes are sizing you up for just exactly what you are."33

When a showman client of his was unable to pay his stabling fees, Wallace acquired some circus equipment. ${ }^{34}$ Partnering with experienced showman James Anderson, the two formed a small wagon circus with a big name: The Wallace and Company's Great Menagerie, Great International Mardi Gras, Highway Holiday Hidalgo and Alliance of Novelties Show. The venture proved profitable and in 1886 it was adapted into a railroad show called the Wallace \& Anderson Circus. By 1890, a disagreement over grift caused Wallace to buy out Anderson's interest in the show. ${ }^{35}$ Grift on the Wallace show was evidently significant, and Wallace made huge profits. ${ }^{36}$ Wakefield wrote, "Wallace had such high class grifters that it was almost impossible for anyone to get a job there unless some other grifter died." ${ }^{37}$ However, dishonest practices and the resulting bad publicity compelled Wallace to change the title of his circus multiple times to avoid recognition. ${ }^{38}$ From 1892 to 1894 it was titled the Cook \& Whitby Circus, and from 1895 to 1906 Great Wallace Shows. ${ }^{39}$ In 1907, Wallace made a covert deal to append a reputable name to his circus.

Carl Hagenbeck was a world-renowned German animal collector and trainer who revolutionized training methods and is considered the father of the modern zoo. ${ }^{40}$ In 1902, Hagenbeck and partners John H. Havlin and Frank R. Tate established a traveling menagerie to tour the American continent. With Hagenbeck preoccupied with other endeavors in Germany, Havlin and Tate converted the show into a railroad circus in late 1905 without Hagenbeck's approval. ${ }^{41}$ After one season, the Carl Hagenbeck Circus proved a loss-making venture, and Havlin and 
Tate looked to sell. Though they were unable to provide clear legal title to the Hagenbeck name, Wallace and his partners bought the physical equipment of the circus in January 1907. Subsequently, Hagenbeck sued Wallace to suppress the use of his name, which he did not want associated with Wallace's. However, the judge ruled that when Wallace bought the circus from Havlin and Tate he also bought the name. ${ }^{42}$ The resulting Hagenbeck-Wallace Circus combination remained one of the most prominent circuses in the country for the next thirty years.

One of Wallace's partners in the purchase of the Hagenbeck show was Jeremiah Mugivan (1873-1930). Mugivan started as a "railroad butcher," selling newspapers and fruit at the railroad depot in his hometown of Terre Haute, Indiana. ${ }^{43}$ It was during that time that Mugivan learned the art of shortchanging. In 1893, he toured with a circus as a ticket seller before spending, in his words, "several years retailing bargains in railroad tickets." ${ }^{44}$ Another account has Mugivan shortchanging and "becoming acquainted with the underworld in general" at the World's Columbian Exposition in Chicago. ${ }^{45}$ In 1900 Mugivan rejoined the circus as an assistant to the legal adjuster. Over the next several years, he managed the privilege car on the Great Wallace Show. ${ }^{46}$

The privilege car was the grifter's domain on a circus train. When a man "had the privilege" on a certain circus, it meant that he specified the games that were to be played and for how long, and received an allotted percentage of all the grifters' winnings. Unlike other employees of the circus, grifters paid for meals and transportation from their own pockets. They rented berths in the privilege car, and also used it for gambling amongst themselves. ${ }^{47}$ 
By the time of Wallace's purchase of Hagenbeck in 1907, Mugivan had established himself as a worthy associate. In the deal, Mugivan was a chief beneficiary of the show's grift. ${ }^{48}$ From 1904 to 1918, Mugivan and his partner Bert Bowers built a circus empire of their own, purchasing and managing such titles as the Van Amburg Wild Animal Circus (later changing its name to Howe's Great London), John Robinson, and Sells-Floto. In 1913, a devastating flood in Peru, Indiana caused the aging Wallace to sell Hagenbeck-Wallace to casino and hotel magnate Ed Ballard, and in 1918, another tragedy, this time a horrendous train crash, motivated Ballard to sell to Mugivan and Bowers. Like Wallace before him, Mugivan came to be known as a major sponsor and philanthropist to the people of Peru. To the rest of the communities visited by his circuses, Mugivan was a notorious and enigmatic figure. ${ }^{49}$

Charles Edward “Ed" Ballard (1874-1936) started his career as a bartender and card sharp in West Baden, Indiana. At the age of 21, Ballard became manager of the casino in the opulent West Baden Hotel. By 1900, he had amassed considerable wealth, real estate, and farmland in the Springs Valley area of southern Indiana. ${ }^{50}$ In 1901 the hotel was destroyed by fire but Ballard quickly secured a position at the nearby French Lick Hotel, where he established an equally successful casino, and in 1908 he took over gambling operations at The Brown, a neighboring casino. ${ }^{51}$ Over the next several years Ballard became immersed in various aspects of the resort business. His purchase of Hagenbeck-Wallace in 1913 fulfilled a lifelong dream of owning a circus and supplemented his other interests by drawing business to the area in the winter. At the end of the 1915 season, Ballard moved the circus into a 
newly constructed farmstead near West Baden, where it would spend the next several winters. Upon establishment of the American Circus Corporation in 1920, Ballard acted as financier and chief executive. ${ }^{52}$ Over the ensuing decade, Mugivan, Ballard, and Bowers artfully operated the American Circus Corporation, the largest aggregate of circuses in existence. The grifting circuses of the ACC clashed with communities and rival circuses alike, particularly that of the newly combined Ringling Bros. and Barnum \& Bailey.

Though it was considered routine at the turn of the century, not all circuses carried grift. The Ringling brothers, who enjoyed a meteoric rise in the circus business, abhorred the practice. Consequently, their circus was dubbed a "Sunday School" show-a common tag in turn-of-the-century show business meant to be derisive. Upon reflecting on their entrance into the circus business in the 1880s, John Ringling was quoted as saying, "Being honest was a matter of conviction rather than of policy. I doubt whether we realized the commercial worth of honesty and good reputation, but we all hated crooks and determined to keep the show clean."53

Begun in 1884 as a simple wagon show starring five of the brothers, the Ringling Brothers Circus rapidly developed into one of the country's largest over the next two decades. When James A. Bailey returned from a multi-year tour of Europe with his circus-heretofore the largest in the country-in 1902, he found that the Ringling show had surpassed his in size and acclaim and had usurped his territory. Upon Bailey's death in 1906, the Ringlings purchased his mammoth show, Barnum \& Bailey's Greatest Show on Earth, operating it independently of their own until after World War One. By 1919, only two of the original five brothers, Charles and 
John, survived, and they determined that a combination was necessary to simplify operations. The resulting Ringling Bros. and Barnum \& Bailey Circus loomed large over its competitors, wielding an exceptional influence over the public's expectations of circus conduct.

In order to repulse would-be grifters, who were always looking for a crowd of people to cheat, "Sunday School" circuses like that of the Ringlings employed their own show detectives. These men were familiar with grifting techniques, and worked with railroad detectives, local police, and sometimes Pinkerton agents to protect circus customers. In the same way that the fixer visits the town saloon (and thence to city hall) to assess the town, show detectives often visited the police station to recruit extra help. Upon visiting a small town police station to assess its effectiveness, the circus detective might find an official "whose criminal experience had been confined to the peaceful country borders,"

who was entirely unaware whether or not the community had been invaded by those who would profit by the lack of worldly knowledge of the thousands of show-day visitors, and whose precautions consisted of the swearing in of numerous deputies, who wore conspicuously a bright badge of office in the happy assurance that it would permit them free entrance to the tent. ${ }^{54}$

An account from the early twentieth century describes a well-known circus detective who was "familiar with the figure, face and method of almost every crook in the circus world."

No person of doubtful or dishonest purpose could remain for more than a few hours in company with the circus without being singled out and summarily dealt with. The treatment varied materially. Its mildness or ferocity rested entirely with the wicked one's conduct after he received the order that he take quick passage out of vision and return no more. .5 
Fixers and circus detectives were significant figures in early twentieth century public life. Studied in the appropriate historical context, circus grift provides a window into the lives of Americans during a turbulent time of growth and change. The friction that resulted among all of these forces-grifting circuses, Sunday School circuses, corrupt and honest civic leaders and businessmendemonstrates the complexity and dissension within American life during the progressive era.

A withering recession in the 1890s led a new generation of reformers to seek alternatives to the laissez-faire tradition of the mid-nineteenth century. ${ }^{56}$ In the 1900s, wrote historian Robert Wiebe, urban reformers sought "a new urban unity" through "scientific government." Rather than allowing city bosses to hand out business contracts and government jobs, these "progressives" sought the more rational system of civil service. By reserving crucial posts for educated "specialists," "civil service promised increasing government service."57 To achieve such a transformation, a popular revolution of thought was required. Educated, middleclass professionals assumed "that every man, properly educated, would desire a functional, efficient society." ${ }^{\prime 5}$ Through rhetoric and legislation, middle class reformers sought to alter the thoughts and actions of the populace and abolish the corruptions of city life. "It is only by a slow and patient inward transformation such as ... laws aid in bringing about," wrote Theodore Roosevelt, "that men are really helped upward in their struggle for a higher life."59

Others tried to inspire reform through more direct methods. The temperance movement, which had begun as a murmur in the late 1870s, steadily 
collected adherents eager to demonstrate their "traditional Protestant

respectability."60 During the Progressive Era, when reformers sought to reform and "revivify the morale of the citizen," the movement reached a critical mass. ${ }^{61} \mathrm{An}$ evocative spokeswoman for the reform of individuals, Carrie Nation led a lively crusade against drink. A devout Christian in her early sixties, Carrie Nation first gained notoriety in the summer of 1900 when she smashed her way through an illegal Kansas saloon with a brickbat. More smashings would follow, leading to numerous arrests. She soon changed her name to "Carry A. Nation" and entered the lecture circuit, where she continued to demonstrate a profound urgency to improve the moral fiber of Americans. ${ }^{62}$

Progressives saw alcohol as a root problem that contributed to prostitution, gambling, and divorce. Drunkenness, they felt, showed a "loss of self-control" and a "celebration of selfishness." 63 Additionally, it was the vice of both the swollen plutocrats and the immigrant multitudes that were most in need of their uplifting influence. ${ }^{64}$ In the years leading up to World War I, the prohibition of alcohol gained support from disparate factions. Northern businessmen who looked toward a more predictable and docile workforce gave the movement an "urban respectability," while presiding Southerners supported the measure because they felt that it would rid them of troublemaking black and poor white drunkards. ${ }^{65}$ The scientific efficiency of progressivism boosted the "old Protestant fervor" into an effective political force. ${ }^{66}$ With such wide support, the Anti-Saloon League successfully influenced major political campaigns and several southern states adopted prohibition in 1907 and 1908. In 1913, Congress passed the Webb Bill, outlawing 
the shipment of liquor into dry states. ${ }^{67}$ But it was patriotism that led to an allinclusive federal ban on alcohol. With U. S. involvement in the war, grain conservation and anti-German sentiment pushed prohibition over the top, and Congress passed the $18^{\text {th }}$ amendment in $1918 .{ }^{68}$

There is some evidence that circus grift declined with the progressive push for more rational urban government. Towards the end of the 1908 season, Variety reported that

'candy butchers' are having a hard time nowadays with some of the circuses. One show, always counted a good berth for the boys, now drives away the butcher who is inclined to 'gyp' the public in anyway [sic]. [...] Grafting of all kinds is growing less popular each year with the managers of tented exhibitions. It may be cut out altogether withing [sic] the next five years, which is more possible than probable since it has endured for nearly half a century. ${ }^{69}$

In a report from the following year, a man astonished by the "tremendous" crowds and "wonderfully clever" show at a Sells-Floto matinee in San Francisco mistakenly gave out a five dollar gold piece. Being "familiar with circus outfits," the man resigned himself to the loss until urged to report it to the circus by the manager at his hotel. "I strutted up to the lot again, pushed my way to the main top, [...] introduced myself, was in turn introduced to [the circus manager], who said: 'So you are the man who paid out that five, eh? Well, here it is. Glad we found the rightful owner."' The man was so amazed that he swore to "let the theatrical world know of this." ${ }^{\prime 0}$ However, any ripples felt on circus lots from Progressivism's splashing reforms were to be short-lived.

Though prohibition was considered a victory for progressives, the urban corruption that they had fought so passionately multiplied after its ratification in 
1920. Where political machines still ruled, "city bosses welcomed the wet vote and cultivated it by letting ward bosses and police captains profit from prohibition through the allocations of liquor privileges in their community." Subsequently, bootlegging gangs made great profits and often infiltrated city governments. ${ }^{71}$ In addition, one agent for the Internal Revenue Service's Bureau of Prohibition in California said that police hesitated to apprehend bootleggers because it would "ruin their underworld contacts," through which they procured leads. Consequently, those breaking federal laws were largely left to gravely underfunded federal officials to apprehend. ${ }^{72}$ These agents were so few in number that bootleggers often came to know them at a glance, making it difficult for them to do their jobs effectively. ${ }^{73}$ In addition, civil service reforms did not apply to federal prohibition agents until 1927. Many were eventually indicted for supplementing their low salaries through graft. ${ }^{74}$

After enduring the sacrifices of the Great War, the progressive mood of Americans had dissolved substantially. In the words of Richard Hofstadter, "The pressure for civic participation was followed by widespread apathy, the sense of responsibility by neglect, the call for sacrifice by hedonism." As a result, Woodrow Wilson and the progressives were "resoundingly repudiated" in the 1920 election. ${ }^{75}$ Senator Warren G. Harding was elected president, winning over sixty percent of the popular vote. With that, Hofstadter writes, "corruption, always more or less normal in state and municipal politics, moved to Washington."76 Harding called for a "return to normalcy," which amounted to the rolling back of several progressive victories and the restoration of laissez-faire business practices. Generally speaking, 
the public seemed to approve. When the press exposed the Harding administration's scandal of oil graft at Teapot Dome in Wyoming, they were labeled "scandal mongers." In the early 1920s, the days of celebrated muckrakers had passed, and the door was open for the American Circus Corporation to practice its "rip and tear" methods of open grifting. In October of 1922, Billboard magazine reported on the resurgence of circus grift after the Progressive era:

One of the chief reasons that bunco artists, swindlers and grafters continue to ply their trade and flourish is because the pickings of the small-town politician and officeholder, which had almost been wiped out, revived enormously with prohibition. [...] The thieving wardheeler and shyster politician ... would have been stamped out altogether ... when along came bootlegging. Protection was openly sought and paid for. [...] Petty politicians, enforcement officials and even policemen waxed fat again. ${ }^{77}$

In December, an exasperated writer for Billboard reported eight instances of various forms of graft in a single issue of a New York daily newspaper. He postulated, "What's a little graft in the show business? Only enough-just enough-to ruin it, and, if allowed to run on, drive every self-respecting man and woman out of it."78

Concurrent to the resurgence of civic corruption, the opposition between the Ringling Bros. and Barnum \& Bailey Circus and the American Circus Corporation reached a fever pitch. Resolved to antagonize each other, the five versatile and agile ACC circuses and the more cumbersome Ringling combination engaged in aggressive "billing wars." Often these were instigated when an ACC circus made an appearance in a city mere days before the Ringling show was scheduled there. For example, in October 1922, Hagenbeck-Wallace was scheduled to appear in Augusta, Georgia on the $23^{\text {rd }}$ and the Ringlings on the $26^{\text {th }}$. Ringling management rushed a cadre of sixty men to the city with the express intention of out-billing the ACC circus 
with advertisements inveigling patrons to "Wait for the Big Show."79 Occasionally the Ringlings had been accused of resorting to this tactic even when it had no intention of appearing at a place, such as in 1910 when a Phoenix newspaper reported, "Sometimes it comes and sometimes it does not, but the effect is generally the same - more or less people remain away from the smaller show, with the expectation of seeing something bigger and better later in the season." ${ }^{80}$

The opposition battles sometimes manifested themselves more directly. Preceding the 1922 season, the Sells-Floto Circus (purchased by the ACC in 1918) scheduled a week long stand in San Francisco September 4 to 11. Upon learning that the Ringling combine had scheduled a coinciding stand, Ballard, Mugivan, and Bowers moved the appearance to an earlier date-the last week of August. Unable to make such a switch but not to be outmaneuvered, Ringling representatives rented a strip of land separating the Sells-Floto lot from the main thoroughfare and erected a fence across it. Upon arriving at the lot, the Sells-Floto Circus found that the fence effectively cut off access to the lot, and it was quickly demolished by one of the show's elephants. A corps of carpenters hired by Ringling management to monitor the fence immediately rebuilt the barrier, and police arrived to ensure that it was not tampered with any further. "As the situation stands, the Sells-Floto Circus, with no Market street entrance, stands to lose several thousand dollars, according to manager [Zack] Terrell," reported Billboard. "Back of the situation is a fight that is said to have been going on for months between the two amusement enterprises." 11

Despite the waning progressive mood in Washington, the Ringlings launched a reform campaign of their own that autumn. In a full-page article in the October 7, 
1922 issue of Billboard, Charles Ringling outlined a plan to expose corruption on and off the circus lots in an article titled, "Let's Get Together For A Graftless 1923." The proposal consisted of two parts: One, the formation of a committee that would collect the routes of all circuses. Secondly, the committee chairman would send a letter to the mayor, city attorney, newspaper editors, school principals, ministers, county sheriff, county attorney, county judge, and a number of other prominent personages in each city on the routes informing them that, "Wherever a circus, carnival, street fair or other show runs games of chance or conducts indecent dancing acts in its side-shows or elsewhere, the local officers of the law have been bribed or fixed." 82 The proposed letter encouraged the formation of "a committee of citizens interested in clean, wholesome amusements [...] to see to it that any circus, carnival, or show that has been advertised to appear in your city is conducted in an honest, decent, moral manner." The letter repeatedly refers to "the good of the children," which are "the best customer[s] of the circus." Ringling also intended to hunt down corrupt officials directly. The following week brought the report of “Charles Ringling's Showmen's Bureau" which intended to establish a "Fact-Finding Agency." Through this agency Ringling intended to compile an index of corrupt civic leaders throughout the country and expose them through the local press. ${ }^{83}$

Ringling was not alone. In September, reports surfaced of the New York Civic League intervening with grift occurring on ACC lots and in some cases making arrests. ${ }^{84}$ Grift was being attacked in other arenas of outdoor entertainment, too. In September, gaming wheels were shut down at the Kentucky State Fair after complaints to the Board of Public Safety. ${ }^{85}$ In December, the National Association of 
Amusement Parks formally condemned gambling devices, "obscene or suggestive" shows of any kind, and "unclean, immoral, or disreputable employees." 86

The response to Ringling's efforts was patently Progressive. One reader wrote, "I trust you will continue until you have established a code of ethics that will enable a man to look the whole world in the eye when he says he is a showman." Another replied, "Let's make a general cleanup. Start with the soul and elevate the moral standard of the showman. If his heart is black it's impossible for him to run a show that will meet with public approval." A third wrote, "The fundamental principles of the success of any business lies in the fact they have several consistent and necessary rules and regulations, combined with a well-arranged system, such features as these being the foundation of the success, viz.: Honesty, truthfulness and an unbounded faith in their calling." 87 A cartoonist submitted a drawing of "The Honest Showman" pushing boulders labeled "Graft" and "Privelege Car" [sic] over a cliff, while "Games of Chance," Short Change," and "Betting Devices" awaited the same treatment. 88

The pressure from "Charlie Ringling's do-gooders" "pulling the Carry Nation stuff" in the words of one ACC employee, compounded an already difficult situation. The American Circus Corporation had experimented with reduced grift earlier in the 1922 season because of the burdensome expectations of corrupt local officials. ${ }^{89}$ Indeed, by the mid-1920s, even Sunday School circuses were expected to give away large numbers of tickets before a license could be obtained. An unfortunate comment by Frank Cook, general manager of Ringling Bros. and Barnum and Bailey that "every small-town official has an immediate family of at least 10 when the 
circus comes to town" led one Pennsylvania official to request 250 free tickets since the board of aldermen there had 25 members. ${ }^{90}$ Officials in San Antonio, Texas notoriously required egregious numbers of free passes. One Billboard reader called corrupt local officers "the boll weevil of the show world" and continued, "the sooner we can sprinkle a little lead arsenic on him the better off we will be. He becomes so bold that he demands his pound of flesh from even the legitimate showman." He then recounts that a small carnival that “didn't have a thing that wouldn't go at a church fair" still had to pay off the local officials. ${ }^{91}$ By 1929, all circus owners, despite their stance on grift, felt resentment over the "circus pass evil."92 With the traditional source of compensation (grift) increasingly squeezed out, circus managers struggled to make a profit. The expensive billing wars between the Ringlings and the ACC quieted through the mid-1920s as each organization attempted to save money, while concession prices on the Ringling show jumped noticeably. ${ }^{93}$ In 1925, American Circus Corporation management found a resolution that would extend their season into the winter, while keeping expenses relatively low. It was a practice that Jerry Mugivan had initiated in 1906 with his very first circus, the Van Amburg Wild Animal Circus. ${ }^{94}$

The Ancient Arabic Order of the Nobles of the Mystic Shrine, colloquially referred to as "the Shrine," was a fraternal organization that grew out of Freemasonry. Since the 1870s, Masonic groups had used annual fairs as fundraisers for the group. ${ }^{95}$ The Shrine enjoyed rapid growth in the early twentieth century, boasting 120 chapters ("temples") by 1910. The "playful, fun loving Shriners" looked to the circus to provide an attractive entertainment to serve as a fundraiser. ${ }^{96}$ In 
1906, the Van Amburg Wild Animal Circus opened its 1906 season in Atlanta, Georgia, under the auspices of the Shrine. ${ }^{97}$

Under this sponsorship system, the sponsor is responsible for securing the venue and paying any licensing fees and for fire and police protection. Frequently the sponsor would also guarantee the circus a certain return for its appearance. ${ }^{98}$ This system would not become commonplace until the mid-1920s with the construction of massive new indoor venues previously only to be found in New York City and Boston. Though the Shrine was subject to the same restrictions on gambling that had plagued the circus during this time, the arrangement was nevertheless mutually beneficial. In the winter of 1923, Hagenbeck-Wallace appeared indoors under the auspices of the Al Sirat Grotto in Cleveland, Ohio's new Public Auditorium. In 1925, elements from three American Circus Corporation shows were combined to produce a full three-ring winter circus in the newly constructed Detroit Coliseum under the auspices of Moslem Temple. ${ }^{99}$ These indoor winter circus productions allowed the ACC to supplement its regular touring income with very few added costs. As there was no opposition, the circus was relieved of advertising the appearance, and since the performance was given indoors, the labor required was drastically reduced. In the 1920s, numerous organizations increasingly utilized this mutually beneficial system, including the Veterans of Foreign Wars, American Legion, Moose, Elks, and even the Ku Klux Klan. ${ }^{100}$ Subsequently, the American Circus Corporation shows and other smaller circuses continued to thrive. 
Though it did not participate in the sponsorship system, Ringling Bros. and Barnum \& Bailey was not unaccustomed to showing indoors. It had traditionally opened its season with an extended engagement in Madison Square Garden in New York City, a practice inaugurated by its predecessor, Barnum \& Bailey’s Greatest Show on Earth. By 1929, the circus was exhibiting nightly for a full month at the Garden. The circus was the Garden's biggest moneymaker (and vice-versa), and John Ringling was a principal shareholder in the venue. However, the Garden was under new management and when it came time to arrange the opening engagement of the 1930 circus season, he requested that the circus not play on Fridays, so that the weekly boxing matches could continue. Ringling refused to bear the expense of tearing down and setting up the circus every week, and bristled at the idea of mixing "my circus with prizefights."101 Assuming that the directors would eventually capitulate, he let the matter drop for the time being. In the meantime, the same offer was given to the American Circus Corporation, who happily agreed to the Friday night clause. A temporary combination of the ACC's best acts, including popular cowboy hero Tom Mix was arranged to play the engagement. ${ }^{102}$ Ringling was infuriated that his tradition was being quashed. Subsequently, the September 21, 1929 issue of Billboard reported a stunning turn:

NEW YORK, Sept. 14. -John Ringling, supershowman, and head of the Ringling-Barnum Circus, has achieved the greatest deal ever consummated in the annals of circusdom by acquiring his five great circus rivals from the American Circus Corporation. The transaction, which was quietly completed in this city, between John Ringling, Ed Ballard, Jerry Mugivan and Bert Bowers, created untold surprise in show circles. ${ }^{103}$ 
John Ringling now owned every major circus in the country. Under Ringling management, any residual grifting practices that may have remained on ACC shows were finally dispelled.

Throughout the 1920s, the progressive impulse of reform was strongly felt by circuses and other outdoor amusement purveyors. That pressure stemmed to some extent from showmen who felt pride for their profession and embarrassment that grift was so pervasive. Significantly though, it also resulted from competition within the field. When Charles Ringling began his crusade of reform, he used showmen's pride to his own advantage. The residual tenor of moral reform of the Progressive Era allowed Ringling to apply a more sophisticated oppositional pressure to its "corrupt" rivals. As suggested by George Stigler in 1971, reform in this case was driven by the largest firm specifically in order to increase the costs (or decrease the profits) of rival firms. ${ }^{104}$ As grift allowed Gilded Age circus managers to pay their huge operating expenses while remaining utterly independent, so the erosion of grift forced circus managers in the 1920s to cooperate with outside organizations for the first time. ${ }^{105}$

1 Scott A. Sandage, "The Gilded Age," in A Companion to American Cultural History, ed. Karen Halttunen (Wiley Blackwell Publishing, Ltd., 2014), 139.

2 Rebecca Menes, "Limiting the Reach of the Grabbing Hand: Graft and Growth in American Cities, 1880 to 1930" in Corruption and Reform: Lessons from America's Economic History, eds. Edward L. Glaeser and Claudia Goldin (Chicago: University of Chicago Press, 2006), 90.

3 Ibid., 65, 69.

4 Joe McKennon, Circus Lingo (Sarasota: Carnival Publishers of Sarasota, 1980), 41.

5 James A. Inciardi and David M. Peterson, "Gaff Joints and Shell Games: A Century of Circus Grift" Journal of Popular Culture Vol. VI No. 3 (Spring 1973): 591-606.

6 Menes, "Limiting the Reach...", 74.

7 Robert H. Wiebe, The Search for Order:1877-1920 (New York: Hill and Wang,1967),12.

8 Ibid., 28. 
9 Menes, "Limiting the Reach...", 77.

10 Billboard, December 2, 1922, p. 7.

11 George Meeker Papers. Miami County Historical Society Museum, Peru, Indiana.

12 Robert C. Sweet, "The Circus: Institution in Continuity and Change" (PhD diss., University of Missouri, 1970), 137.

13 "Friction with Business Office" Show World, July 27, 1907. Accessed February 24, 2015. http://circushistory.org/ShowWorld/ShowWorld1907.htm

14 "How to Eliminate the Circus Pass Evil" Billboard, January 12, 1929. Accessed March 2, 2015. http://circushistory.org/History/CircusPassEvil.htm

15 James Saxon Childers, "Inside Workings of a Great Circus” Bandwagon, Vol. 21, No. 1 (Jan.-Feb. 1977), 17. First published in Birmingham (Alabama) News Age Herald September 28, 1930.

16 Dr. Edwin H. Sutherland, "Circus Grift by and Old Circus Grifter: Based on Correspondence with Glenn H. Wakefield," 1938?, 10. Dr. Edwin H. Sutherland papers, private donation to author. For information about this collection, please contact the author.

17 David W. Maurer, The American Confidence Man (Springfield: Charles C. Thomas, 1974), 90.

18 Sutherland, "Circus Grift by an Old Circus Grifter," 10-12.

19 Ibid.,15-16, and Maurer, American Confidence Man, 231.

20 Sutherland, "Circus Grift by an Old Circus Grifter," 9.

21 Childers, "Inside Workings...", 17.

22 "The Shady Side of the Circus Business" New York Tribune, October 1, 1922, Magazine section.

23 Sutherland, "Circus Grift by an Old Circus Grifter," 8A.

24 Ibid., 9A.

25 "Shady Side of the Circus Business" and "Pete Cristiani recalls Joe Louis, grift on Dailey Bros. Circus" accessed March 11, 2015. https://www.youtube.com/watch?v=R0oQG3sYwM\&feature=youtu.be

26 "Shady Side of the Circus Business"

27 Sutherland, "Circus Grift by an Old Circus Grifter," 26.

28 William (DeLavoye) Lambert, Show Life in America (Will DeLavoye, 1925), 24.

29 Sutherland, "Letters \& Manuscript" 16.

30 Bert J. Chipman, Hey Rube! (Bert J. Chipman, 1933), 134.

31 Maurer, American Confidence Man, 148.

32 George and Ferol Meeker, "Ben Wallace and the Early Circus in Peru, Indiana" 17th Annual Official Souvenir Program, Circus City Festival, 1976, p. 50.

33 Al D. Beasley, Twentieth Century Peru (1899), 51.

34 Chalmer Condon, “Benjamin E. Wallace's Winterquarters” Bandwagon, July-August 1964, p. 7.

35 Beasley, 47 and from "James Anderson, Veteran Circus Man, In Feeble Health" Peru Daily Chronicle, June 21, 1910: "Anderson fought uncleanliness and graft in his day and believed in leaving a town so that the citizens would delight in having him return."

36 Maurer, American Confidence Man, 179.

37 Sutherland, “Grifter Bios," Kid Hunt.

38 Peru [Indiana] Republican, June 16, 1944.

39 Robert L. Parkinson, Directory of American Circuses:1793-2000 (Circus World Museum, 2002).

40 John Culhane, The American Circus: An Illustrated History (New York: Henry Holt and Co., 1990), 290-1, "Carl Hagenbeck" accessed March 12, 2015. http://en.wikipedia.org/wiki/Carl_Hagenbeck

41 Fred D. Pfening, Jr., "How Wallace Bought Hagenbeck" Bandwagon, July-August 1964, p. 11.

42 Ibid., 12.

43 Harry Sarig. Interview by George and Ferol Meeker. 1971? Meeker papers, Miami County Historical Society Museum, Peru, Indiana.

44 “Jerry Mugivan Tells How It Was Done" Billboard, March 19, 1921, p. 16.

45 Sutherland, "Glenn H. Wakefield," 2.

46 Ibid.

47 Sutherland, "Letters and Manuscripts," 18.

48 Pfening, 11.

49 Mugivan was rarely photographed. In 1923, the New York Clipper wanted to run a story about this 
man and his rise to prominence in the circus world. A caption read, "Mr. Mugivan's picture is not easy to obtain. For a while it seemed to be a secret, but the above photo was finally dug up."

50 Charles Edward "Chad" Ballard, Charles Edward "Ed" Ballard: A Story of Determination, SelfEducation, and Ultimate Success, comps. Janet Kirk Johnson and Anna Marie Borcia (C. E. Ballard Literary Trust: 1984), 31-2.

51 Ibid., 32.

52 Interview with Sarig, Meeker papers, Miami County Historical Society Museum, Peru, Indiana.

53 John Ringling, "We Divided the Job-But Stuck Together" In Fox, A Ticket to the Circus (New York: Bramhall House, 1959), 40. Originally published in The American Magazine, September 1919.

54 W. C. Thompson, On the Road with a Circus (1903). Accessed February 24, 2015. http://circushistory.org/History/OnRoad3.htm\#X.

55 Ibid.

56 Richard Hofstadter, The Age of Reform: From Bryan to F. D. R. (New York: Random House, 1955), 166-7.

57 Robert H. Wiebe, The Search for Order, 1877-1920 (New York: Hill and Wang, 1967), 161, 168.

58 Ibid., 170.

59 Michael McGerr, A Fierce Discontent: The Rise and Fall of the Progressive Movement in America, 1870-1920 (New York: Oxford University Press, 2003), 80.

60 Wiebe, Search for Order, 56.

61 To quote Hofstadter, Age of Reform, 257.

62 McGerr, Fierce Discontent, 82-3.

63 Ibid., 84-5.

64 Hofstadter, Age of Reform, 290.

65 Wiebe, Search for Order, 291.

66 McGerr, Fierce Discontent, 87.

67 Ibid., 89.

68 Ibid., 294.

69 Variety, October 17, 1908, p. 14. Accessed September 22, 2014. http://circushistory.org/History/Variety1906.htm\#1908.

70 "Observations of the Stroller," Billboard, June 5, 1909, p. 3.

71 Julien Comte, "'Let the Federal Men Raid"': Bootlegging and Prohibition Enforcement in Pittsburgh" Pennsylvania History Vol. 77, No. 2 (Spring 2010), 167, and William E. Leuchtenburg, The Perils of Prosperity, 1914-1932 (Chicago: University of Chicago Press, 1993), 215.

72 Oscar J. Jahnsen. Interview by Alice King and Miriam Feingold Stein. 1976. Earl Warren Oral History Project. University of California Berkeley Bancroft Library,

http://nma.berkeley.edu/ark:/28722/bk0005z1x6f. Transcript pp. 38-9.

73 Comte, "Let the Federal Men Raid," 169.

74 Ibid., 170.

75 Hofstadter, Age of Reform, 281-2.

76 Ibid., 286.

77 "Grafting Police and Crooked County Officers" Billboard, October 21, 1922, p. 5.

78 “Graft! Graft!! Graft!!” Billboard, December 2, 1922, p. 71.

79 "Ringlings Send Flying Squad of 60 Men Against Hagenbeck" Variety, October 20, 1922, p. 8. Accessed March 18, 2015. http://www.archive.org/stream/variety68-192210\#page/n103/mode/2up/search/Ringling

80 "First Guns in Circus War Fired in the West" Show World, April 23, 1910 (vol. V, No. 18). Accessed September 22, 2014. http://circushistory.org/ShowWorld/ShowWorld1910.htm

81 "R.-B. and S.-F. Shows Battling in Frisco" Billboard, September 2, 1922, pp. 7, 103.

82 Charles Ringling, "Let's Get Together for a 'Graftless' 1923” Billboard, October 7, 1922, p. 53.

83 "To Smoke Out the Local Graft Fixer" Billboard, October 14, 1922, p. 5.

84 "Suppressing Bad Conditions" Billboard, September 23, 1922, p. 70.

85 Billboard, September 23, 1922, p. 5.

86 "Graft and Immorality Condemned" Billboard, December 1, 1922, p. 19.

87 "Outdoor Forum" Billboard, November 4, 1922, p. 88. 
88 "Clearing the Field" Billboard, October 14, 1922, p. 108.

89 "Significant If True" Billboard, September 16, 1922, p. 64. "Sells-Floto and Hagenbeck-Wallace have cut out the "connection" but still have "joints" in each side-show."

90 Variety, May 17, 1923, p. 10. Accessed March 17, 2014.

http://www.archive.org/stream/variety70-1923-

05\#page/n105/mode/2up/search/\%22Frank+Cook\%22

91 See note 87.

92 "How to Eliminate the Circus Pass Evil" Billboard, January 12, 1929. Accessed March 2, 2015. http://circushistory.org/History/CircusPassEvil.htm

93 See note 87. Sam Fowlkes of the Dallas Chamber of Commerce wrote to complain that soft drinks, normally five cents, cost circusgoers twenty cents at a recent stand.

94 John H. McConnell, A History of the Shrine Circus: Mystic Shriners Yankee Circus in Egypt (Detroit: Astley \& Ricketts, 1998), 41.

95 Ibid., 39.

96 Ibid.

97 Ibid., 41.

98 Robert C. Sweet and Robert W. Habenstein, "Some Perspectives on the Circus in Transition" Journal of Popular Culture Vol. VI No. 3 (Spring 1973), 587.

99 McConnell, History of the Shrine Circus, 89.

100 Ibid., 98.

101 David C. Weeks, Ringling: The Florida Years, 1911-1936 (Gainesville, FL: University Press of Florida, 1993), 218.

102 Ballard, Charles Edward "Ed" Ballard, 89.

103 Billboard, September 21, 1929, p. 52.

104 Edward L. Glaeser and Claudia Goldin, "Corruption and Reform: An Introduction" in Corruption and Reform: Lessons from America's History, eds. Edward L. Glaeser and Claudia Goldin (Chicago: University of Chicago Press, 2006), 17.

105 Sweet, “The Circus...", 141. 
CHAPTER THREE

NEW PRESSURES:

INDUSTRIAL DEMOCRACY AND THE CIRCUS

As the nineteenth century came to a close, nearly half the population of the United States belonged to a working class that performed manual labor for wages. ${ }^{1}$ A dense web of railroads crept ever westward, connecting budding urban centers, transformed by new possibilities of manufacturing. From the factories and mills of the east to the fields and mines of the south and west, these laborers relied on their employers for their meager sustenance. The majority of the country's wealth and power was held by a mere two percent of the population. These wealthy capitalists controlled much of what happened in the country, both economically and politically. ${ }^{2}$ Where work was found, danger and death lurked, from the black lung and cave-ins of the mines to tuberculosis and mangled limbs in mills and factories. ${ }^{3}$ Wages were low, and employment was unsteady. Despite the great wealth of their employers, workers found it difficult to support themselves, let alone their families. During the last quarter of the nineteenth century, workers on railroad circuses experienced similar conditions. Typifying the sentiment of the age, circus owner James A. Bailey considered these workers “dispensable," and found hiring a different work crew in every city preferable to providing decent wages and working conditions. ${ }^{4}$ Under this system of exploitation, the circus thrived. Over the next three decades, American workers undertook the struggle to secure a fair standard of 
living from their employers. Despite its position on the fringes of American society, the circus felt increasing pressure to adapt to prevailing viewpoints. Following trends in heavy industry, circus laborers would eventually seek increased security. As a result, the circus was unable to continue operating in its traditional manner.

Even apart from the presentation of skill and daring inside the tent, the logistical pageant that occurred on the circus lot mesmerized a new populace every day. On circus day, large crowds gathered at the train yard at dawn to watch the circus unload. Hundreds of men worked like clockwork through the morning with the help of scores of draft horses and elephants to transform hulking bales of canvas into a wavering, living city of canvas covering up to eleven acres. A midway lined with colorful banners and concessions directed patrons toward the dominant and voluminous big top that housed the main performance, and the menagerie top, filled with an eclectic array of animals from all over the world. To a large degree, this free spectacle of labor was essential to the success of the circus. It was a tremendous free form of advertising, especially after the daily street parades were discontinued in the 1920s. It was also singularly dependent on inexpensive laborers who expected little of their employers.

The largest circuses employed hundreds of laborers. By and large, workingmen, particularly in the unskilled positions, were not with the show for very long. As in the factories, most of these men were faceless cogs in a massive machine, and often nameless as well. For the benefit of management, the workingmen were sometimes required to wear numbered badges. ${ }^{5}$ Many were transients, just looking for work and transportation to a certain place. In articles written for Bandwagon, 
circus fan Sverre Braathen often quoted the statistic that workingmen stayed with the circus an average of nine days. This trend shows up in mass culture too, in the Marx Brothers film, A Night At The Opera (1935), when Chico remarks, "Circus?

When was I with the circus? Oh, that was a long time ago-last week." Consequently, circus managers were usually busy recruiting replacement laborers after reaching a large city. A few days of rain and mud could also cause a mass exodus of workers. ${ }^{6}$

Moreover, even though management attempted to obtain it, often a worker refused to give a name when he was hired. Circus men instead relied on nicknames to identify each other. A person's race might earn them the nickname "Blackie," "Whitie," or "Red." A man with a missing limb might be called "Peg." One man, who showed up on the lot wearing a cork helmet was dubbed, "Stanley, the African Explorer."7 Sometimes they were named after their state or city of origin. If they resembled a historical figure, they would assume that name..$^{8}$ Other examples include "Hamburger Joe," Silent Waxey," and "Canned Heat Mickey." In an extreme case of hidden identity, circus trouper Bert Chipman relates a story about a "delicate looking middle aged fellow" who was unable drive tent stakes on the sledge gang, and was given a job setting up stages inside the side show tent. "One day while apparently ill, the fellow fainted while handling a heavy trunk. One of the ladies connected with the side show administered aid and on opening the shirt collar discovered one of her own sex!"10

Those who stayed with the circus for an extended time or through multiple seasons were often men who were single, homeless, or otherwise detached from society as a whole. Those laborers who made a commitment to the circus were said 
to be "with it and for it." This phrase was a demonstration of loyalty to the show that housed and fed them, and distinguished circus men, or "troupers," from the rest of the populace, or "towners." For those adherents of the traditions of the circus, it was also a great source of pride. Long time circus trouper Joe McKennon wrote, “...If you are with and for a show, it becomes your show. The circus, you feel, is something living and precious that needs your protection."11 Though less prevalent, the terms "circus simple" and "sawdust in his veins" were alternative ways of expressing this devotion. Those who were "with it and for it" remained season after season, and they formed the core of labor necessary for an uninterrupted work schedule. $^{12}$

Like that of the factories, circus work was dangerous. Aside from railroading accidents, which killed thousands of people every year, ${ }^{13}$ the swarm of activity caused by setting up and tearing down the circus every day created a hazardous environment. Workingmen were susceptible to the occasional runaway wagon, as it rolled down the runs off the train. The polers, who guided wagons along the decks of flatcars, were said to have the most dangerous job on the circus. A stone or cinder under a wheel could make the wagon tongue jerk suddenly to the side, breaking the man's legs. ${ }^{14}$ Canvasmen were similarly vulnerable to the forty quarter poles that propped up the sidewalls of the big top, each of which weighed over six hundred pounds and had to be raised and lowered every day. ${ }^{15}$ Circus laborers were also inclined to fighting amongst themselves, and occasionally killed one another. ${ }^{16}$ In addition, working outdoors near mosquito infested swamps in the hot southern summers sometimes brought outbreaks of malaria. Recounting one such 
victim, Chipman says, "There was no means of notifying relatives. We only knew that he had joined out at some point in Northeastern Iowa. Another unknown soldier, that's all."17

In 1901, less than ten percent of workers in the United States belonged to unions, and many of those were craft unions of male, skilled workers. ${ }^{18}$ The squashing of the Pullman strike in 1894 had demonstrated the dominance of capital over labor. The Populist crusade of reform, which once seemed to hold so much promise for the workers of the south and west, was also quashed by $1900 .{ }^{19}$ Though mutual aid associations and trades unions still championed mutualism over the old Victorian individualism of the elite, their numbers were small..$^{20}$ The industrial order seemed safe on circuses as well, since no such organizations existed among the ranks of circus workingmen.

Because of the transience and diversity of its workforce, the circus rarely experienced attempts at unionization or strikes of any kind. After the circus obtained new iron orchestra-style seats with footrests, the workingmen of the Barnum \& Bailey Circus mounted a brief strike in 1903 because of the weight of the cumbersome new equipment. They demanded a five dollar per month raise. Management responded by simply replacing them. ${ }^{21}$ In addition, circus rhetoric suggested that its workers were contented to live and work in impoverished conditions. "His work is hard and he knows little else. Good work is enough for happiness if more people only knew it," one circus author wrote.

Toiling from daybreak into the wee small hours of another day, the circus laborer is happy in the world that he has found to be his very own. Frequently he sings as he works, curious chanty-like odes that come from the inner rhythm of his being. He is building. And he is 
glad. Tomorrow today's town will be but a dim memory. But his world will be with him. And that is good. ${ }^{22}$

During World War One, the recruitment of young men for the war effort combined with the curtailment of European immigration sharply increased the demand for labor throughout the country. Unemployment in 1918 was a mere 1.4 percent. ${ }^{23}$ However, sharp inflation and a 102 percent rise in the cost of living between 1914 and 1920 put pressure on workers to somehow improve their station in life. Many bounced from place to place, searching for a decent wage. Labor scouts haunted circus lots looking to recruit men. In a 1980 interview, press agent John C. Kunzog said that circus workingmen in the least skilled positions were paid $\$ 10$ on a monthly basis in 1917 . One man, after leaving the circus to work in a factory, came back to the show but requested a weekly stipend for buying beer. "So for fifty cents cash every Monday, plus their ten dollars a month, they were satisfied and a lot of them stayed."24

While the circus was able to placate its workers in this instance, circuses suffered substantial labor shortages during the war, performers and laborers alike. Performers from throughout Europe left in aid of their countries in 1915, and those remaining were asked to "double up" on extra acts and to assist with manual labor. ${ }^{25}$ Upon U. S. entry into the war, the Barnum \& Bailey Circus retained only eighty of its usual two hundred and fifty canvasmen. Equestrian director Fred Bradna recalled, "Many a day I helped to drive two hundred stakes before 6 A.M., then moved fifty trunks into the ladies' dressing tent" before resuming his normal duties. ${ }^{26}$ Shorthanded, the remaining staff of the circus demonstrated the "with it and for it" credo—an attitude that was becoming increasingly outmoded. 
Laborers in other fields took advantage of their newfound leverage by staging an unprecedented number of strikes and lockouts in an attempt to gain control of their working conditions. ${ }^{27}$ By the end of the war, workers in steel mills, coal mines, and shipyards—even Broadway actors picketed for fewer weekly performances under the auspices of Actors Equity—contributed to a nationwide air of unrest. ${ }^{28}$

Unfortunately for labor reformers, progressives were out of power and out of style by 1922. President Wilson's failing health and preoccupation with the organization and acceptance of the League of Nations led to concessions to conservatives. The ensuing Republican administrations of Harding, Coolidge, and Hoover did little to protect the working class from the will of corporate capitalists. ${ }^{29}$ Instead, employers began to mount a new strategy for appealing to workers.

Lizabeth Cohen describes the adoption of welfare capitalism by large companies as a response to increased working class militance and government intrusions into corporate autonomy. Rather than assuming "that the interests of management and labor inevitably conflicted," employers hoped to create a mutualistic "industrial democracy" in which each employee was oriented toward the company. ${ }^{30}$ Where there was strife and demands, welfare capitalism sought to create a compliant, non-union workforce through stock ownership plans, incentive pay systems, company dances, and other benefits like vacation and sick pay. These sorts of benefits were designed not only to soothe discord, but also to quell turnover rates by offering pensions for loyal, continuous service. ${ }^{31}$ But throughout the 1920 s, conditions in the factories were still poor, wages low, and the hours long. According 
to Cohen, "Manufacturers found it easier to sweeten the icing than to enrich the cake itself." 32 Though welfare capitalism failed miserably to deliver on its promises, it nevertheless created a workforce that was unified in its expectation of a square livelihood.

Many of welfare capitalism's key benefits were unavailable to circus managers due to the transient and seasonal nature of the enterprise and the unwieldy expenditures it would require. Circus managers had always practiced a certain degree of welfare capitalism, in that they provided food and lodging for their employees as part of their pay. However, circuses did not provide sustenance for the majority of its workers beyond that necessary to reach the next town. This fact alone placed circus laborers in the category of the working poor. Writers on the circus often indicate that low wages were necessary to keep workingmen sober enough to perform their duties. It is also apparent that the show offered laborers in the least skilled positions small fringe benefits to keep them placated. "They drank up their two bucks (the show gave them two packs of Bull Durham [tobacco] or two cans of Snooze [sic] Copenhagen snuff along with their pay each week) but they were ready for work at seven AM Monday morning," McKennon wrote. "Give them five (dollars), they wouldn't have been able to work before Wednesday, if at all."33

Despite traditional rhetoric suggesting that circus workers were complaisant in their circumstances, the profound labor unrest after World War I likely affected them likewise. Though hard evidence is scant, circus workers in unskilled positions worked in a myriad of industries and were therefore subjected to the cultural influences of the outside world. For circus managers, they also made up a 
regrettable majority. Whether workers were straying from the "with it and for it" credo or just outnumbered, such sentiments became increasingly outmoded in the 1920s.

If employers' record for providing steady work with a living wage was spotty during the 1920s, it was dreadful during the Great Depression. The railroad sidings and campfires of circus workers and other roaming laborers grew crowded as whole families became dispossessed, creating Hoovervilles. By 1933, eight million people were unemployed in the United States. ${ }^{34}$ As banks failed and unemployment and hunger ran rampant, those who had lived and worked under the thumb of wealthy industrialists at the turn of the century saw their sons and daughters inheriting the same grim existence.

The Great Depression hit the entertainment industry hard. Despite a 33 percent reduction of ticket prices, movie theatre attendance dropped from about ninety million per week in 1930 to sixty million in 1933, leading to the bankruptcy of several major film studios. ${ }^{35}$ Broadway productions were scaled down and the number of productions reduced, putting many in the theatrical profession out of work. Billboard estimated that half of those employed in show business in 1929 were jobless in $1937 .{ }^{36}$

Circuses were no exception. Throughout the thirties, small and mid-sized shows folded or were shelved by their management. What made the Depression particularly hard on circuses was the near monopolization of the industry created when John Ringling, last surviving of the original famous brothers, bought the American Circus Corporation in September of 1929. Ringling management 
subsequently put the best acts and equipment on its flagship show and routed it into areas most likely to yield a return. The rest were either taken off the road or left to pick up the scraps. By 1931 there were only five active railroad circuses remaining, four of which were controlled by Ringling. ${ }^{37}$ This dearth of competition also limited the employment options for circus troupers. Ringling management could set the pay scale for workers and performers. W. W. Wilno, who developed his human cannonball act in Germany before being brought to the United States in 1929 by circus booking agents said, “If you don't do business with [Ringling], you just left in the cold. Accept his offer. He only pay you so much, take it or leave it. Now what are you going to do?"38 More than ever, the Ringling Bros. and Barnum \& Bailey Circus was the linchpin of the industry.

As the Depression progressed, American workers began to claim their constitutional rights. ${ }^{39}$ But workers no longer looked to their employers for financial security. In the 1930s, a "new radical culture" formed among American workers in which the working class assumed its own powerful voice and found appreciation from the arts. As Michael Denning has shown, the Popular Front represented a "laboring" of American culture wherein "politics' captured the arts, when writers went left, Hollywood turned Red, and painters, musicians, and photographers were 'social minded."'40 Denning selects the year 1934 as "an emblem of insurgency, upheaval, and hope."41 While the Popular Front built upon earlier movements of radicalism such as the International Workers of the World (IWW) and the woman's suffrage movement, it was most symbolically represented by the rise of a new industrial union determined to organize unskilled workers in 
the automotive, steel and electrical industries called the Committee for (later Congress of) Industrial Organizations, or $\mathrm{CIO}_{4}^{42}$

Concurrently, President Franklin Roosevelt's New Deal policies found wide support from the Popular Front as practical solutions to the concerns of workers. In a 1937 study by Sociology professor Arthur W. Kornhauser, the overwhelming majority of Chicago workers were found to support intervention by the federal government and labor unions. The New Deal garnered a 90 percent approval rating among unskilled workers and only slightly less that among semiskilled. More than 80 percent of those interviewed favored strong labor unions for all, as protection against self-indulgent big businessmen. Suddenly, Americans were looking to the government for relief, jobs, and security, and many wrote pleading letters directly to the president out of desperation. ${ }^{43}$

At a time when the elderly were a poverty population, some circuses managed to find work for their "old timers," taking tickets in the sideshow or performing odd jobs at winter quarters. ${ }^{44}$ Though this arrangement was rare, it demonstrates further the paternalistic order suggested by the "with it and for it" circus credo.

One of the most significant pieces of New Deal legislation to affect the circus was the Social Security Act. In March and April of 1937, Billboard published a series of articles titled "The Social Security Act As It Affects Outdoor Amusement Fields." With stern language, the articles assure show owners that "the Internal Revenue Bureau, Washington, D. C., which is the enforcement agency of the law, is very much determined to make every show owner and show employee live up to the letter of 
the law." 45 The Act, which gave federal assistance to the elderly, disabled, and unemployed through a payroll tax, required employers to keep detailed records of each employee, including correct name, age, and address. Nobody was to be employed without first providing their Social Security card-“your personal account with the government." In addition, total wages for each worker were to be figured, including meals and sleeping accommodations, and reported to the government. Each employee must also receive a receipt showing wages due and tax withheld. ${ }^{46}$ Any laborers with the circus for more than one day were "considered as regular employees and subject to the tax."47 Exempted from the tax were "bona fide circus performers who make their living exclusively by the exhibition of unusual feats, and freaks of the side shows, who would not be able to do any other work." 48

The Social Security Act put an expensive new encumbrance on circus bookkeepers, and created incentive for maintaining a steady workforce. Whereas the traditional system of transient labor kept wages low, the situation was reversed with passage of the SSA. One circus accountant said that "it costs more today to keep tax records on a show the size of Hagenbeck-Wallace than it took to actually run it." 49 Furthermore, with proper identification a prerequisite for employment, transients wishing to stay off the government's radar were kept off the circus payroll. The same trouper said that prior to the SSA, "circus took up a certain slack in employment-people who couldn't work anyplace else. That same type of person today is on the float with no place to go." ${ }^{50}$ The result was a much more standardized and rationalized workforce. With an established nationwide standard of living for retirees, the Social Security Act transformed both the dynamic between 
the circus and its workforce and the very makeup of that workforce. A standardized and steady workforce also facilitated circus unionization.

When the National Industrial Recovery Act was passed in 1933, the section 7(a) gave workers the right to "organize unions of their own choosing." However, the NIRA contained no protections against company unions or anti-union tactics. ${ }^{51}$ In three months, 3,537 new AFL federal locals were chartered, but the AFL was weak and ineffectual. Employers readily resisted recognizing these haphazardly formed unions, and fired those who joined, sparking another wave of strikes. ${ }^{52}$

Finally, President Roosevelt had to take a stand against big business. The National Labor Relations Act, more commonly referred to as the Wagner Act, was passed in the summer of 1935 and was considered to be the most radical labor legislation ever enacted. Labor historian James R. Green writes that the Wagner Act "finally gave federal recognition to the rights workers had been asserting for more than a century..."53 The Wagner Act guaranteed employees "the right to selforganization, to form, join, or assist labor organizations, to bargain collectively through representatives of their own choosing, and to engage in concerted activities for the purpose of collective bargaining or other mutual aid and protection." It also prohibited employers from intruding upon this process in any way. Senator Robert Wagner, who drafted the Act, believed that collective bargaining could create a power balance between capital and labor that was essential for economic stability. ${ }^{54}$ According to Columbia University law professor Mark Barenberg, Wagner accepted that the capitalist ownership of production was an established fact, but he also believed that true industrial democracy could bring about a "renewed culture of 
democracy-from-below." ${ }^{55}$ It was therefore "profoundly cooperationist."56 In April of 1937, the Supreme Court upheld the constitutionality of the Wagner Act. Resistant employers grudgingly began to comply..$^{57}$

After a year of struggle, President Roosevelt was able to pass the Fair Labor Standards Act that same year. The FLSA established a minimum wage and a fortyhour workweek, but applied only to interstate commerce. Though it was far weaker than the president intended and did not apply to circus workmen, the commerce jobs that were covered by the FLSA may have become more desirable to the itinerant circus laborers.

Into this world came the American Federation of Actors (AFA), a subsidiary of the American Federation of Labor. It was led by ex-vaudevillian Ralph Whitehead with the primary intention to unionize actors and performers within the legitimate theatre and vaudeville. In December of 1936, representatives from twenty-one different theatrical unions met at the Manhattan Opera House to discuss their concerns over the recent cuts to the WPA theatre project. Seven months earlier, Whitehead had complained to the WPA about perceived discrimination against vaudeville, and insisted upon the creation of a federal "Vaudeville, Musical Comedy, and Circus" project. Evidently this project went nowhere and Whitehead proceeded to apply for charters in those fields under the AFA.

Meanwhile, the CIO continued to make gains. Unorganized workers scrambled to find employment in CIO organized industries. ${ }^{58}$ The burgeoning industry of culture—screenwriters, cartoonists, actors, directors, and even circus performers and workmen-waited impatiently. When asked whether the CIO 
planned to organize show business, representatives demurred, stating, "While extent of theater biz is appreciated, it is not considered one of the more fruitful fields for early activity." ${ }^{\prime 9}$ Due to the looming shadow of the CIO and the positive effects of the Second New Deal, the AFL added 886,000 new members in 1937.60

The circus took pains to reassure its audience that circus workers were satisfied with their working conditions. In the official program for the Ringling Bros. and Barnum \& Bailey 1936 season, a hypothetical interview with a circus laborer asks about the "hardships of his life." "Nothing to that at all," replies the fictitious "oldtimer." The article's author maintains that

it will not occur to them that theirs is a hard lot. They eat the best three times daily and they eat all they want. Their food's the same as the big boss eats, too, they'll add. What's more, every man jack of them has a berth in a show sleeping car on one of the four long circus railroad trains. [...] The Big Show has man power in plenty, and it has the railroad car room to make for comfort. ${ }^{61}$

Even in the midst of such tumultuous times when labor was organizing all around them, circus audiences preferred to think of the circus as impervious to such strife. The circus was to be an escape from the daily turmoil of the depression—a reminder of "the days when enthusiasm could be aroused over something less ponderous than a brain trust," opined The Washington Times, "The days when relaxation was found in discussing something besides the deviousness of economic law."62

Those who were able to maintain jobs through the WPA Theatre project were earning wages far above what they would normally receive. ${ }^{63}$ Some actors claimed that the $\$ 23.86$ weekly wages paid by the WPA was causing "nonprofessionals" to "cash in on the benevolence of the WPA administrators." ${ }^{64}$ Whitehead was 
relentless in his attempt to gain as much ground for the AFA as he possibly could. He claimed to have secured "endorsements" from over two hundred theatrical agencies that had agreed to the AFA rules, including its wage scale and closed shop stipulation. These agencies would then theoretically promote membership to their clients before the AFA would grant them a license. ${ }^{65}$ Bookers, emcees, dancers, and even singing waiters applied for AFA licenses. The AFA also published an "unfair list" to discourage the patronage of businesses trying to side-step their efforts. ${ }^{66}$ When circuses began their 1937 season in mid-April, business was picking up. Production, wages, and other economic indicators had returned to 1929 levels and many felt that the worst was behind them. As the economy enjoyed an upswing, audiences were eager for amusement. The Ringling Bros. and Barnum \& Bailey circus played to near-capacity houses during its first four nights at Madison Square Garden. ${ }^{67}$ The Hagenbeck-Wallace circus (now a Ringling subsidiary) set attendance records in Chicago. ${ }^{68}$ The 1936 season had been the best for business since the onset of the Great Depression, and 1937 was looking even better. The Cole Bros. and Dan Rice shows also reported excellent business. Circus press agent Bob Hickey compared the comeback of the circus to a referee's generous "long count" in a boxing match, exclaiming, "here they are, bright and merry and back on their feet again in 1937 and bicycling into the big folding money."69 The circus business was booming once again, and Ringling manager Sam Gumpertz made a bold move. Whether it was the general sense of optimism or the self-assuredness of Whitehead, something caused Gumpertz to sign an unprecedented union contract with the AFA. 
"UNION FOR CIRCUS WORKMEN" was the blaring headline on the first page of Billboard magazine on May 22, 1937. "AFA organizers approached workingmen on the Brooklyn lot this week and reported the signing of several hundred membership applications." Gumpertz encouraged "all of the employees of the circus" to join the union. Billboard acknowledged that this was the first time that a union attempted to organize outside of the performers' field. Circus billposters had been unionized under the International Alliance of Billers and Bill Posters for many years, and circus band members likewise were organized under the American Federation of Musicians. Gumpertz remarked, "No trouble has arisen with them and there is no reason to believe the AFA will be any different."70

Evidently the negotiations for organizing the workingmen went smoothly. Gumpertz told the press, "I am very happy at the outcome and feel that we will have no trouble on the road with labor groups which previously charged that our personnel was non-union. I firmly believe that this closed-shop agreement with the AFA is better for the circus management. And I want to compliment Ralph (Whitehead) for his splendid actions, co-operation and fairness in all our dealings." ${ }^{71}$ Approximately 1,500 performers and workingmen signed AFA member applications. The workingmen, who made up a large majority of this number, received a staggering $\$ 30$ per month pay boost, setting the minimum wage on the Ringling Bros. and Barnum \& Bailey Circus at $\$ 60$ per month, plus board, lodging, and transportation aboard the train..$^{72}$ Wages would be reduced to $\$ 30$ per month when the circus was in winter quarters. This contract was to run for five years. ${ }^{73}$ 
Whitehead assured circus management that a "Circus Employees' Division" would be formed within the AFA.

Significantly, the five year agreement included clauses intended to guarantee stability. In section 8 of the contract, "The employer agrees to make no deductions from the salaries of the employees excepting ... initiation fees and dues of the members of the union when payable and due." And in section 13, "The parties hereto agree that there shall be no lockouts or strikes during the term of this agreement because [of] any matter of controversy or dispute between the employer and the union or a member thereof." It continues, "in the event that the parties hereto are unable to settle the differences amicably within 10 days the matter shall be referred to a board of arbitration". ${ }^{74}$

The union was less successful attempting to organize the smaller circuses. Hagenbeck-Wallace decided to form its own independent union. ${ }^{75}$ Citing the Wagner Act and good old-fashioned circus autonomy, Cole Bros. management also refused to endorse the AFA to its employees. Whitehead's representative was evidently hospitalized after being assaulted by Cole Bros. workingmen. ${ }^{76}$ Eventually Whitehead visited the circus himself and was finally able to secure an agreement for a closed shop contract with the AFA with a $\$ 40$ minimum wage. ${ }^{77}$ In addition to its pathbreaking circus contracts, the AFA had gained over twenty new contracts with burlesque houses, music teachers, chorus girls and the like by the end of the year. ${ }^{78}$ Everything seemed to be looking up for the circus business. Billboard reported that "circus has been making a comeback and should continue with agricultural and industrial conditions favorable. The circus is a clean and wholesome amusement 
and people will continue to patronize the white tops as long as they are offered worth-while programs."79

Before the year was out, the Ringling Bros. and Barnum \& Bailey circus was reclaimed by the Ringling family. John Ringling had died in 1936. Nephews John and Henry Ringling North, both graduates of Yale, had been written out of their uncle's will but still yearned to regain the family business from Gumpertz. John Ringling-North had managed to obtain a loan for the remaining $\$ 800,000$ mortgage on the circus and he subsequently fired the existing directors. John (always referred to as "Johnny" by circus staff, perhaps to avoid confusion or perhaps out of passive derision) assumed the title of executive vice president and named his brother vice president. Gumpertz was out.

When the circus opened the 1938 season at Madison Square Garden, trouble started almost immediately. North had announced that he would not abide by the contract signed by his predecessor. ${ }^{80}$ The extended indoor stands at the Garden and then in Boston were the biggest moneymakers of the season, and he refused to pay the full $\$ 60$ wage scale until the circus began its season under canvas in Brooklyn since the workingmen had substantially fewer responsibilities during indoor engagements. Despite a no-strike clause in the contract, Whitehead evidently encouraged the workingmen to strike. ${ }^{81}$ A total of about 200 workers including property men, wardrobe employees, animal help, grooms, porters, concessions men, drivers and some ushers walked out just before the evening performance of April 12. Summoning the time-honored tradition that the show must go on, North explained the situation to the audience (who had already arrived) and the 
remaining staff and performers attempted to exhibit as much of the show as they could manage. Performers wearing enormous costumes walked rather than rode horses and elephants in the usually grand opening "spec." The North brothers, the sideshow giant, performers, and even a few audience members helped set up and tear down the big iron cage for Terrell Jacobs' big cats act. Henry Ringling North says, "How long the show ran that night I don't exactly know, because nobody checked. But it was dawn by the time John and I, with our faces blackened and our evening clothes in tatters, got back to the Ritz. We never wanted another night like that. But the strikers had really done us a favor. The publicity was magnificent." 82 Indeed, the New York Times ran a photograph of several attractive "girl performers" pushing the enormous air conditioned wagon that held the circus' star attraction, Gargantua the gorilla. ${ }^{83}$ After two days of this, the State Mediation Board stepped in and a compromise was met. The men would be paid on a $\$ 45$ per month scale in New York and Boston. ${ }^{84}$

Once the circus reached Brooklyn and began its season under canvas, Whitehead attempted to show good faith, and waived the fines for the performers who did not join in the New York strike. He pointed out, however, that there were about seventy who had not yet signed with the union, which had a closed-shop agreement, and therefore had not paid any dues. Furthermore, the circus had not encouraged them to do so. This, he said, broke the union contract, which stipulated that the show should aid in the collection of dues. The performers responded that "we don't see why we should pay dues to an organization that spends it on 
unnecessary strikes against the show that pays, feeds and keeps us throughout the season." ${ }^{85}$ Ultimately North had to cover the cost from his own pocket. ${ }^{86}$

On June 4 in Harrisburg, Pennsylvania, North announced that if business did not improve, all employees would be subject to a 25 percent pay cut effective on the nineteenth. He never intended to include the union in this decision. ${ }^{87}$ Instead, he attempted to reason with the workingmen. On June 6 in Pittsburgh, North addressed all employees:

The purpose of this enterprise, if perhaps some of you have never paused to analyze it, is to bring entertainment to a large cross-section of the American public and by so doing to return to the corporation a fair profit. In order to accomplish this purpose, it is necessary to purchase large quantities of materials, employ many men, and engage a large number of performers. [...] All of this, as you all know, must and does require expenditure of a great deal of money. You must also know that in good times the circus does big business and makes good money. [...] [But] these, gentlemen, are not normal good times. Last year you men received a raise in pay that, in some instances amounted to $100 \%$. [...] I now repeat that I receive no satisfaction from having to ask you to take a $25 \%$ reduction, save perhaps the satisfaction of knowing that ... I am ... assuring you of work with a fair living wage for the remainder of the season." ${ }^{88}$

The workingmen were unmoved. On June 14 in Toledo, sixty-seven teamsters walked out. This time, North was prepared. He immediately divested himself of the three hundred baggage horses, which had traditionally loaded and unloaded the train, and replaced them with eighteen tractors. North was not concerned with the free spectacle that the horses provided or the crowds which had gathered to watch them for generations. He was now free of the problems of feeding, transporting, and handling them and the men who managed them. ${ }^{89}$ In exchange, he put the show's performing horses on display in a tented paddock. The sale of the baggage horses netted the circus $\$ 115,000 .{ }^{90}$ 
The pay cuts went into effect in Watertown, New York on June 18. Four days later, the circus arrived in the union stronghold of Scranton, Pennsylvania. Here, the union could enjoy the political leverage of a pro-union city. A general membership meeting of the union was called to discuss a plan of action. Though North had posted a notice that the advertising agents had decided to accept the pay cut, ${ }^{91}$ the entire remaining personnel including performers and a reported nine hundred workingmen went on strike. ${ }^{92}$ There were no performances, and the circus could not move. It was stranded. In an era of labor violence and professional strikebreakers, the mood in Scranton was tense. The debonair equestrian director Fred Bradna and his wife Ella were pelted with rocks by labor-friendly pickets and the Norths were "besieged" at their hotel. ${ }^{93}$

After four days, the performers changed their minds. They began circulating petitions to end the strike and continue their route. But without the support of the workingmen's majority, the efforts of the performers proved futile. The laborfriendly mayor of Scranton was nonetheless getting antsy about getting the marooned giant out of town. When no arrangement could be reached, he declared the circus a "menace" to public health and presented it with a bill for $\$ 2,180$ for the city's expenses protecting the show. ${ }^{94}$ Finally North announced that a continuation of the season was impossible and he intended to move the circus back to winter quarters in Sarasota. By June 25, a document had been drawn up dissolving the contract, and North was forced to pay the AFA $\$ 12,000$ in strike costs and wages for a crew of 150 to get the circus back to Florida. ${ }^{95}$ Before signing, the union asked 
that the word "strike" be eliminated from the document, claiming that they had actually been locked out. The request was denied. ${ }^{96}$

Although North may have been justified in requiring wage cuts to save the season, both employer and union had run roughshod over the original AFA contract. Whitehead's encouragement of the strike was in direct violation of the "no strike" clause in section 13. Likewise, the contract called for a board of arbitration to be formed consisting of "three members, one selected by the union, one selected by the employer and a third agreed upon by the two so selected. In the event that the third party cannot be found acceptable to those hereinbefore mentioned, the entire controversy shall be referred to the American Arbitration Association." No such board was ever formed. Ironically, both parties expected the other to concede for the same reason-to continue the tour. In the fallout of the strike and ostensible closing of the circus, New York's Herald Tribune called the strike "one of the most stupid and unpopular blunders ever committed in the name of organized labor." The Capital Times of Madison, Wisconsin was similarly outraged, calling the strike "a prize boner in labor strategy-one that demonstrates how quickly labor can lose prestige through dumb and irresponsible leadership." ${ }^{97}$

North was not giving up on the season of 1938 . There was one show still on the road from the American Circus Corporation deal, and it had never been unionized. As soon as the mammoth Ringling Bros.-Barnum \& Bailey show had limped into Sarasota, North began making plans to send its feature acts west to join up with the Al G. Barnes-Sells-Floto circus in the Dakotas. Twenty railroad cars were loaded with the big show's cookhouse, stock, performers and equipment. The 
performers signed new contracts with much reduced salaries. The new conglomeration, "Al G. Barnes-Sells-Floto Circus Presents Ringling Brothers and Barnum \& Bailey Stupendous New Features," opened at Redfield, South Dakota on July 7.98

The AFA continued to follow the show and picket its performances. The picket line at Janesville, Wisconsin was broken with elephants, which according to some accounts, were swinging tent stakes in their trunks. The front page of the $A F A$ Reporter was dominated by the headline, "TRUTH ABOUT CIRCUS LOCKOUT." One story pledged, "The AFA intends to unionize the Barnes show and to teach North that contracts are not scraps of paper." It indicated that notices were being sent to city delegates along the route that "Ringling and Barnes show are on the 'Unfair List.' This means that millions of union members and their families will will [sic] not patronize those shows." 99 The circus responded by placing ads in local newspapers assuring people that

Al G. Barnes-Sells-Floto Combined Circus presenting Ringling Bros.Barnum \& Bailey's stupendous new features is most friendly to organized labor and exclusively employs union musicians, billposters, treasurers, ticket sellers, agents, and press representatives, all of whom are fully paid up members of The American Federation of Labor and in good standing. Spend your union dollars at home at the big show.

Finally, the Madison Capital Times published a front-page story strongly discouraging picketing of the circus there. It read, in part:

We have been assured by representatives of the Circus Fans Association in Madison that the majority of the workers in the Barnes Circus are members of the Union. [...] We have also received information that the union members with the Barnes Circus are opposed to picketing of the show, because they fear such agitation 
may force the circus to cancel all future engagements, thereby throwing them out of work.

The press agent with the circus bought dozens of copies of this paper and distributed them over the rest of the route. The circus had no further pickets the remainder of the season. ${ }^{100}$ However, with its AFA entanglement, it had taken an unprecedented step into an increasingly bureaucratized American society.

In the fallout of the circus union debacle, the AFA lost its AFL charter.

Whitehead had received permission to organize circuses, but the AFL was unaware that he intended to include non-performers. ${ }^{101}$ A new union called the American Guild of Variety Artists was awarded the charter and given jurisdiction over vaudeville, night clubs, circuses, and carnivals. They immediately re-signed the performers on the show. AFL president William Green was unable to locate any indication in union records that circus workers or stagehands were ever under the union's jurisdiction. He stated that "When a union desires to extend its jurisdiction or acquire additional jurisdiction it must make formal application to the executive council of the right to do so. That's the law and the procedure of the AFL."102 In addition, the AFA was found guilty of using union dues inappropriately to pay executive salaries and for the purchase of a new car for Whitehead in a 1939 trial.103

The 1938 season was perhaps the worst that the circus industry had ever experienced. ${ }^{104}$ Of the twenty or so circuses that went on tour in the spring of 1938 , at least ten of them folded before November. Despite the high hopes of the preceding year, members of the Circus Fans Association and the Circus Saints and Sinners Club of America felt that action was necessary to "keep the circus from going the way of the small-town opera house." Like thousands of Americans had done, the 
groups appealed to President Roosevelt for help. They circulated petitions "asking the President to come to the aid of the circus-and soon."105 After the Scranton debacle, some doubted that the Ringling "sheet anchor" show would ever tour again. A Michigan newspaper cried, "'The Show Must Go On'-is that, too, one of the things of yesterday that doesn't belong with the modern generation?"106

Clearly, the Ringling Bros. and Barnum \& Bailey Scranton strike of 1938 did not represent the "industrial democracy" that Robert Wagner had striven to foster with the National Labor Relations Act. In fact, the "recommendation" of the AFA by Gumpertz to circus employees was likely the kind of thing that the Wagner Act was intended to restrict, since it prohibited employers from intruding upon the organization process. In addition, the methods Whitehead employed in conducting votes on the union have been called into question. ${ }^{107}$ When North refused to honor the contract signed by Gumpertz a year earlier, he probably believed that he was preserving the circus. However, the attitudes of the workingmen fell decidedly in preference of the union.

Of course, the Ringling Bros. and Barnum \& Bailey Circus did tour in 1939, but it was unlike any other circus Americans had seen before. Most noticeable was the transformed big top. Traditionally the circus' main tent had been white. The journal of the Circus Fans Association of America was (and is) called White Tops. It was also extremely long and narrow. The new tent was blue and more rounded in order to improve the effectiveness of another new concern-lighting design-during the matinees. Not only did this improve the vision of spectators, but it also required 
fewer simultaneous performers in order to engross them. ${ }^{108}$ This was by design, since the 1939 edition of the show was geared to employ as few as possible.

Secondly, the hundreds of horses that had always loaded and unloaded the train had been permanently replaced by Caterpillar tractors. A new machine designed to pull tent stakes was employed, as well as one that could guy out (tighten and secure) tent ropes-"an operation which had been performed by large gangs of men." ${ }^{109}$ After seeing this machine in action and deciding to use it, the North brothers felt briefly wistful that "never again would we hear the resonant chant of 'Heebie! Heebie! Hobie! Hold! Golong!' which was the euphonious rendition of 'Heave it! Heave it! Heavy! Hold! Go on!'"110 All of these innovations drastically reduced the number of men that the circus needed. Though Whitehead had finally been convinced to accept a twenty-five percent pay cut for the duration of the five year contract, North refused to hire any more than the bare minimum.

The theme of the 1939-1940 World's Fair in New York City was "The World of Tomorrow." As cultural historian Morris Dickstein writes, the thirties "devoted itself to imagining a sleek, streamlined consumer culture..."111 Thus "streamlining" became a catchphrase for design. John Ringling-North was so impressed with the General Motors display "Futurama" that he hired its designer, Norman Bel Geddes, to redesign the circus for 1941. Circus fans in the media, at least, were shocked. The New York Times and over two hundred other newspapers across the country ran editorials about it. ${ }^{112}$ The majority of these were blasting North for abandoning circus traditionalism. 
Bel Geddes answered the criticisms with an article in The New Republic. "The news that I had been retained by the North boys to redesign the Ringling Brothers and Barnum and Bailey Circus brought across my desk as many editorials as would ordinarily come out of a political campaign. Up until that time I had not realized that this honest intent could be so laden with dire possibilities." ${ }^{113}$ But the design and engineering possibilities of such a large-scale operation entrenched in tradition were clear to him. Bel Geddes intended to push mechanization, replace the wagons "in their baroque grandeur" with "a new type of wagon, lighter, stronger, and easier to transport." The menagerie tent's interior would become a "simulated jungle." The music, posters, and lighting would all be overhauled in order to cater to "a people that have had the modern impact of two world's fairs." The big top itself would be engineered so that no interior poles would be necessary, thus improving sight lines for everybody. Bel Geddes reassured those concerned that "No iconoclastic feet will tread down the sacred idol of this or the passing generation. The job, in its essentials, is a necessary one and should not be deplored any more than adding fire-escapes and exits to some beloved theatre."114 Some of these "streamlining" efforts, like the new big top design, failed to materialize. Others, like a "free range" type of enclosure for the monkeys in the menagerie were jettisoned early in the season. The new, supposedly efficient innovations caused "numerous late arrivals and consistently delayed matinees" that season. ${ }^{115}$

While the circus had traditionally operated on the fringes of society, those fringes began to contract during the twentieth century. Where previously it was able to avoid entanglements with state and local governments, the circus was 
nevertheless a capitalistic enterprise subject to economic shifts and federal legislation.

In his $1971 \mathrm{Ph}$. D dissertation on the circus, Robert C. Sweet referred to a study by economists William J. Baumol and William G. Bowen about the dilemma of productivity and capital in the performing arts. Their point was that "unlike workers in manufacturing, performers are not intermediaries between raw material and the completed commodity - their activities are themselves the consumer's good." Therefore, "every increase in money wages will be translated automatically into an equivalent increase in unit labor costs-there is no offsetting increase in output per man-hour as there is in a rising productivity industry."116 In the unique case of the circus, this point is applicable to laborers as well as performers. The circus presentation, equally reliant on laborers and performers, was the end product for sale. Despite the adoption of tractors, stake drivers, or other methods of mechanization, the effects of these devices on the circus were negligible in comparison to the effects of technology available to industrial production. Sweet's conclusion was that increasing output per man-hour in those industries led to increasing wage demands across the board. The fallout of Whitehead's attempts to unionize circus laborers and guarantee them a high wage suggests that the circus could not adequately keep pace.117

The anachronistic labor requirements of the circus assumed that its workers had no desire for domestic or financial stability outside of its canvas walls. With some coaxing from a zealous Whitehead, the "with it and for it" attitude that had gotten the circus through so many scrapes in the past began to crumble. Though the 
performers eventually capitulated to the circus due to their highly specialized talents, John Ringling North's Scranton address to his workers in which he defined "The purpose of this enterprise" as "to bring entertainment to a large cross-section of the American public and by so doing to return to the corporation a fair profit" echoed too closely the individualism of nineteenth century big business owners that circus workers were rejecting. But many observers, like circus author and lecturer George Brinton Beal, felt that the "grand old patriarchal system" was "as much a part of circus life as the beautiful ladies in pink tights and the big red wagons and [elephant] line."118

The highly traditional nature of the circus was much beloved by the public, who saw the circus as a nostalgic (and nationalistic) cultural staple. However, the increasing demands of American workers for financial security in the 1920s and thirties challenged the circus to adapt. John Ringling North's changes to the operative functions and the performance of his circus created a functional model for the institution going forward. But a 1939 New Republic editorial suggested that the new streamlined circus was "sick"-a disgraceful effort and hardly a circus at all. "Anybody knows what the Circus has got and the best of all its qualities is its aroma of fantastic extravagance. Nothing so big as an elephant and we've got fifty, nothing so daring as the man of the flying trapeze or so clumsy as a bear." The columnist was able to find at least one concurring voice. "'It's a crime,' the elephant handler said. 'They want a circus but they don't want to pay for it. So they complain that business is bad. But this country's got enough people to keep five good shows going, if you give them what they want. This show? It's killing circus business."'119 
1 Michael McGerr, A Fierce Discontent: The Rise and Fall of the Progressive Movement in America (New York: Oxford University Press, 2003), 15.

2 Robert H. Wiebe, The Search For Order: 1877-1920 (New York: Hill and Wang, 1967), 22.

3 McGerr, Fierce Discontent,16-7.

4 Janet M. Davis, The Circus Age: Culture and Society Under the American Big Top (Chapel Hill: University of North Carolina Press, 2002), 68.

5 Ibid., 41.

6 Ibid., 68.

7 Bert J. Chipman, Hey Rube! (Bert J. Chipman, 1933), 136.

8 Davis, Circus Age, 68.

9 Joe McKennon, Horse Dung Trail: Saga of the American Circus (Sarasota: Carnival Publishers, 1975), 447.

10 Chipman, Hey Rube!,138.

11 McKennon, Horse Dung Trail, 291.

12 Robert C. Sweet, "The Circus: Institution in Continuity and Change." PhD diss., University of Missouri, 1970, 106.

13 James R. Green, The World of the Worker: Labor in Twentieth Century America (New York: Hill and Wang, 1980), 21.

14 Tom Parkinson and C. P. Fox, The Circus Moves by Rail (Newton, NJ: Carstens Publications, Inc., 1993), 162.

15 Henry Ringling North and Alden Hatch, The Circus Kings: Our Ringling Family Story (Garden City, NY: Doubleday \& Co., Inc., 1960), 314.

16 Davis, Circus Age, 188.

17 Chipman, Hey Rube!, 137.

18 McGerr, Fierce Discontent, 32.

19 Wiebe, Search for Order, 92, 105.

20 McGerr, Fierce Discontent, 17.

21 Davis, Circus Age, 80.

22 George Brinton Beal, Through the Back Door of the Circus (Springfield, MA: McLoughlin Bros., Inc., 1938), 54, 55.

23 Green, World of the Worker, 92.

24 John C. Kunzog, interview by Nels Juleus and John Hanners, 27 July, 1980, Circus Oral History Project, personal collection.

25 Fred Bradna and Hartzell Spence, The Big Top: My Forty Years with The Greatest Show on Earth (New York: Simon and Schuster, 1952), 90.

26 Ibid., 93.

27 Green, World of the Worker, 90.

28 McGerr, Fierce Discontent, 303-4.

29 Ibid., 309, 315

30 Lizabeth Cohen, Making A New Deal: Industrial Workers in Chicago, 1919-1939 (New York: Cambridge University Press, 1990), 160.

31 Ibid., 174.

32 Ibid., 187.

33 Joe McKennon, Logistics of the American Circus: Written by a Man Who Was There (Sarasota, FL: Carnival Publishers of Sarasota, 1977), 16.

34 Green, World of the Worker, 135.

35 "The Depression and Industry Finances," Film Reference, accessed March 9, 2015, http://www.filmreference.com/encyclopedia/Criticism-Ideology/Great-Depression-THEDEPRESSION-AND-INDUSTRY-FINANCES.html

36 "Half of Show Biz Jobless" Billboard, July 10, 1937, p. 4.

37 "Gasoline Gipsies of Circus Land" Literary Digest, April 25, 1931, p. 42. 
38 W. W. Wilno, Interview by Nels Juleus and John Hanners, June 10, 1980, Circus Oral History Project, personal collection.

39 Green, World of the Worker, 134.

40 Michael Denning, The Cultural Front: The Laboring of American Culture in the Twentieth Century (London: Verso, 1996), xvi.

41 Ibid., xiv.

42 Ibid., xvi, 4.

43 Cohen, Making A New Deal, 252-3.

44 C. P. Fox, A Ticket to the Circus: A Pictorial History of the Incredible Ringlings (New York: Bramhall House, 1959), 98.

45 "The Social Security Act As It Affects Outdoor Amusement Fields" Billboard, March 20, 1937, p. 53.

46 Ibid., March 27, 1937, p. 39.

47 Ibid., April 3, 1937, p. 44.

48 Ibid.

49 George Meeker Papers. Miami County Historical Society Museum, Peru, Indiana.

50 Ibid.

51 Green, World of the Worker,140-1.

52 Mark Barenberg, "The Political Economy of the Wagner Act: Power, Symbol, and Workplace Cooperation" Harvard Law Review, Vol. 106, No. 7 (May 1993), p. 1435, note 256.

53 Green, World of the Worker, 150.

54 Barenberg, “Political Economy..., 1423.

55 Ibid., 1426.

56 Ibid., 1381.

57 Cohen, Making A New Deal, 302.

58 Denning, Cultural Front, 7.

59 "CIO Not Interested in Show Business Now, But Maybe Later" Billboard, March 20, 1937, p. 3.

60 Green, World of the Worker,158.

61 "Just A Few Looks Into The Lives Of The Big Show Artists And Workers" Ringling Bros. and Barnum \& Bailey Magazine and Daily Review, Season of 1936, p.24.

62 "Circus Parades, We Need Them" Washington Times, quoted in Billboard, September 1, 1934, p. 38.

63 "WPA Boys in the Dough" Billboard, March 27, 1937.

64 "23\% of Federal Theater Performers are 'Phonies"' Billboard, January 23, 1937.

65 "AFA Gets 200 Endorsements" Billboard, April 10, 1937, p. 34.

66 "AFA Issues 'Unfair List"” Billboard, April 17, 1937, p.11.

67 "Ringling Near-Capacity Houses First 4 Days at MSG" Billboard, April 17, 1937.

68 "H-W Smashes Some Records in Chicago" Billboard, April 24, 1937, p.38.

69 “The Circus Does a 'Tunney'” Billboard, June 12, 1937, p. 39.

70 "Union For Circus Workmen" Billboard, May 22, 1937, p. 3.

71 "Big Show Flies AFA Banner" Billboard, June 5, 1937, p. 96.

72 Ibid.

73 Ernest J. Albrecht, A Ringling By Any Other Name: The Story of John Ringling North and His Circus (Metuchen, NJ: Scarecrow Press, Inc., 1989), 68.

74 “A 'Circus City' Falls-Why?" Billboard, July 2, 1938, p. 29.

75 "H-W Employees Form Independent Union" Billboard, July 10, 1937, p. 36.

76 Ibid.

77 “Cole Signs Closed Shop Contract With AFA; Minimum Wage Is \$40" Billboard, September 11, 1937, p. 3.

78 No title. Billboard, November 27, 1937, p. 27.

79 "Larger Shows Fare Best in 1937" Billboard, January 1, 1938, p. 74.

80 Sverre Braathen, "The Sheet Anchor Failed" Bandwagon, Vol. 16, No. 3 (May/June 1972), p. 27.

81 Albrecht, A Ringling By Any Other Name, 69.

82 North and Hatch, The Circus Kings, 279.

83 "Gargantua Gets A New Escort as Strike Hits Circus" New York Times, April 14, 1938. 
84 Ibid., 70.

85 "Climax of Wrangling Between R-B, AFA Expected This Week" Billboard, May 14, 1938.

86 Albrecht, A Ringling By Any Other Name, 71.

87 Ibid., 72.

88 Braathen, "The Sheet Anchor Failed" 27-8.

89 North and Hatch, The Circus Kings, 282.

90 Albrecht, A Ringling By Any Other Name,104.

91 Braathen, "The Sheet Anchor Failed" 28.

92 "But the Show Didn't Go On" New York Times, July 3, 1938 and Braathen, "The Sheet Anchor

Failed" 28.

93 Fred Bradna and Hartzell Spence, The Big Top: My Forty Years with The Greatest Show on Earth

(New York: Simon and Schuster, 1952), 144 and North, 283.

94 Albrecht, A Ringling By Any Other Name, 75.

95 North and Hatch, The Circus Kings, 284.

96 Albrecht, A Ringling By Any Other Name, 76.

97 Braathen, "The Sheet Anchor Failed" 28-9.

98 Ibid., 29.

99 "North Tried to Break Union, Men, But Failed" AFA Reporter, July, 1938. Reprinted in Braathen,

"The Sheet Anchor Failed" 29.

100 Braathen, "The Sheet Anchor Failed" 30-31.

101 "Whitehead Chided on Actor's Policy" New York Times, July 13, 1939.

102 "Green Questions Rights of Actors" New York Times, August 9, 1939.

103 "Stage Union Loses Its A.F.L. Charter" New York Times, July 15, 1939.

104 "'Save the Circus!' They Cry" New York Times, August 14, 1938.

105 Ibid.

106 Lane Talburt, "Amid Ruins of 1938 Season Last Two Railers Made Big Showing in Atlanta"

Bandwagon (November/December 2010), 51.

107 McKennon, Horse Dung Trail, 450. "As in all other Whitehead organizational campaigns, no vote was ever taken covering the full complement of employees."

108 Albrecht, A Ringling By Any Other Name, 102.

109 North and Hatch, The Circus Kings, 291.

110 Ibid., 292.

111 Morris Dickstein, Dancing in the Dark: A Cultural History of the Great Depression (New York: W.

W. Norton \& Company, 2009), 362.

112 Albrecht, A Ringling By Any Other Name, 106.

113 Norman Bel Geddes, "Streamlining the Circus" The New Republic, January 20, 1941.

114 Ibid.

115 Albrecht, A Ringling By Any Other Name, 110.

116 Sweet, "The Circus..." 247, 249.

117 Ibid., 250.

118 “Hartmann's Broadcast” Billboard, July 30, 1938, p. 29.

119 Bruce Bliven, Jr., “Long Live the Circus!” The New Republic, May 22, 1939. 


\section{CONCLUSION}

The story of the response to corruption and labor struggles on circus lots provides an opportunity to explore the factors of decline within the American circus, and also illustrates the two distinct paths the circus took through the second half of the twentieth century and beyond. While smaller circuses continued to appear under the auspices of various community groups, the Ringling Bros. and Barnum \& Bailey Circus made drastic changes to the traditional circus format in an effort to maintain solvency. Common to both was a general shrinkage, as circus purveyors struggled to retain entertainment value amidst unkind conditions. Although generations of wistful circus patrons have been demanding a return to what they considered a true, "out and out circus" as far back as 18941, the changes incurred in the middle decades of the twentieth century seem to have fundamentally altered the distinctive essence of the circus-going experience.

Foremost of these changes was the circus' increased accessibility. When the American Circus Corporation shows began appearing under the auspices of community and fraternal organizations, it signified a drastic change in policy. The

circus, traditionally autonomous and recalcitrant towards society at large, relied on its elusiveness. Its affiliation with an increasingly rationalistic and bureaucratic mainstream society had transformative implications. 
The particular mystique of the circus had always depended upon various levels of deception-grift, humbugs, and wildly exaggerated advertisements, called "ballyhoo." For example, some grifters claimed that the public enjoyed being hoodwinked as a part of the anarchic circus-going experience:

It is a queer thing, but an absolute fact, that a large proportion of the people who attend circuses, especially in outlying districts, expect to find [crooked] games in operation. Unless the have a chance to try a shell game or something of the sort they feel that they have been deprived of a part of their legitimate amusement. ${ }^{2}$

Though his circus never adopted the custom of grift, John Ringling conveyed a similar attitude while commenting on the bombastic claims made by circus posters in a 1919 American Magazine article, claiming that "there is no effort to deceive the public — but to express the hugeness of everything in figures that carry the idea."

If we have fifty elephants and say a hundred, it pleases rather than offends. On circus day, everybody wants to think and talk in big figures, because on circus day we are boys and girls again, and we want to believe that there are a hundred million trillion elephants in the parade, and a billion funny clowns, and whole bushels and bushels of beautiful ladies on white horses. ${ }^{3}$

However, after transferring administrative responsibilities to its sponsor, circus managers became more vulnerable to the whims of their rational and bureaucratic audience. By 1930, the circus had to be much more careful about staying true to its word. Ringling Bros. and Barnum \& Bailey press agent Dexter Fellows said that

You don't see, these days, so many daredevil acts, like the loop-the-loop on a bicycle and such. When they sign an act now they make sure that it can play out the season. You advertise a loop-the-loop, and then the fellow falls and breaks a leg; then when you get to the next town, there's a terrible squawk from the customers. They won't believe you ever had such an act.

It was that way with John Daniel II, the only gorilla in captivity. He 
was always getting sick and couldn't be taken from his car, and every time he didn't appear, as advertised, it gave the show a black eye.

Similarly, customers familiar with circus deceptions objected loudly if an advertised parade failed to materialize due to a late arrival. "They never would understand that we tried and failed. They believe that a circus can do anything, and when you slip up on something, they think you are deliberately buncoing them."4

The lengthening tendrils of the federal government also unearthed resistance on the part of circus managers to establishing financial accountability and forced more formalized procedures. President Franklin Roosevelt and chief advisor Harry Hopkins attacked local corruption throughout the New Deal in order to ensure trustworthy disbursement of relief funds through the Federal Emergency Relief Act (FERA) of 1933 and the Works Progress Administration (WPA) of $1935 .^{5}$ The WPA featured a "division of progress investigation" which allowed Hopkins to address complaints of corruption on a city-by-city basis. ${ }^{6}$ Confidence men engaged in elaborate cons through the U. S. mail found that unlike local governments, the federal government during the New Deal "could and would exact a penalty whenever con men violated federal law," and considered federal officials to be "almost incorruptible."7 As rising income taxes, a federal amusement tax, and strict bookkeeping methods plagued circus owners, some believed that they could still elude the government. A Billboard article from May of 1936 reveals the "[f]lagrant evasions of laws, unallowed exemptions and slipshod [bookkeeping] methods" of some circuses and the considerable influence of the federal government during the New Deal:

The Collector of Internal Revenue at Washington, where all payments 
of federal taxes are checked and compiled, has received during the last two years a number of complaints from local deputy collectors stating that the owners of outdoor shows in many instances are not living up to the law, and it seems to be the opinion in official circles there that some show owners are "trying to get away with something."

It is impossible to "chisel" the federal government out of anything that it has coming. The culprit is always caught, even tho [sic] it may take a little time, and there is no such thing as "fixing."

Finally, traditional practices of recruiting laborers along the circus route and carrying them throughout the country became impossibly complex. After a trapeze artist hired by Ringling Bros. and Barnum \& Bailey in Boston, Massachusetts was injured during a performance in Cincinnati, Ohio, she sought $\$ 78,000$ from the Ohio State Insurance Fund in a case of the Ohio State Court in 1940. The circus denied negligence in the case, and asserted that since its business was "of a migratory nature, resulting in employment of individuals whose services are rendered in many states while on circuit," it had no obligation to participate in the State Insurance Fund of Ohio, and that the Ohio Workmen's Compensation Act was "not applicable" to its business. However, the court ruled in favor of the injured performer, stating, "the residence of the employer and employee is not determinative of the question presented." ${ }^{9}$ The implication that the circus must carry liability insurance for each state in which it appeared only further burdened the suffering institution. The circus' inevitable submission to the processes of urbanization, bureaucratic thought, and centralized power marred its distinctive ethos of deception and independence. But the circus-going experience also changed in more tangible ways.

Of paramount importance was the shift to indoor venues. Though John Ringling's purchase of the American Circus Corporation and the ensuing Great Depression effectively put an end to the ACC circus titles (Feld Entertainment, 
Ringling Bros. and Barnum \& Bailey's current parent company uses HagenbeckWallace and Sells-Floto as the names of its scenic design shop and concessions subsidiary respectively in order to maintain legal ownership of them), numerous "truck shows," circuses that traveled in caravans of trucks rather than on trains, appeared during World War Two, and many of these continued the practice of appearing indoors under the auspices of the Shrine and other groups. During the war, the circus enjoyed a brief resurgence as a popular nationalistic entertainment. New patriotic programming and a dearth of competition allowed Ringling Bros. and Barnum \& Bailey to continue touring under canvas relatively successfully throughout the war years. The downsized and "modernistic" circus of the 1940s featured increased production values, comfort, and "vastly more inviting and attractive ... decorative features" than previously, which caused some observers to complain that it had "gone Broadway."10

Ultimately, the "Greatest Show On Earth" also moved indoors. In 1956, the Ringling Bros. and Barnum \& Bailey Circus folded up its canvas tents for good. Despite public outcry, John Ringling North deemed the move necessary for the continuation of the circus as an entity. Indoor performances simplified both the bureaucratic and practical logistics of such a complex production and the circus had become increasingly reliant on receipts from its opening stands at Madison Square Garden and Boston Garden. ${ }^{11}$

With the move to indoor arenas, the circus lost its "strangeness of atmosphere ... that can not be associated with every day settings." 12 The cavernous big top tent, unique to circuses, was a significant element of the circus-going 
experience. In the 1930s, the conclusion of the indoor engagements garnered excitement from circus observers. When it began its tour under canvas, one wrote, "The performance attained its real strength and magic. [...] The show hit its deserved stride and put the engagement in Madison Square Garden in the shadows." ${ }^{13}$ Unapologetically romantic, these "unintentional" aspects of the tented circus production, when added to the "intentional" elements of the circus performance, wrote circus critic David Hammarstrom, "suggest the romance and mystical splendor of the circus. And rightly so! [...] The circus makes an art of romance, a joy of sentimentality.... This aspect of the circus is not of little significance; it is of great significance! It can not be overlooked."14 The circus-going experience was therefore fundamentally transformed.

Ultimately, the United States had become a much smaller and interconnected place in the early twentieth century. No longer could the circus evaporate into the night with its ill-gotten gains or recruit a new mob of laborers at each stand. Although Progressive Era legislation rarely applied to the circus directly, circus history closely follows the contour of that era due to the changing moods of regular people. It was the rhetoric of moral uplift that allowed Charles Ringling to effectively curb circus grift, even while political machines still reigned. As workers across the country made steady gains, circus laborers turned away from the traditional "with it and for it" attitude, demanding fairer conditions and more security. However, progressive moods of reform, bureaucratic thought, an enlarging state, and the end of the "grand old patriarchal system" of labor also meant an end to the "aroma of fantastic extravagance" that had made the circus a fantastically 


\section{popular amusement.}

1 Ernest Albrecht, From Barnum \& Bailey to Feld: The Creative Evolution of the Greatest Show on Earth (Jefferson, NC: McFarland \& Co., Inc., 2014), 41.

2 "The Shady Side of the Circus Business," New York Tribune, October 1, 1922.

3 C. P. Fox, A Ticket to the Circus: A Pictorial History of the Incredible Ringlings (New York: Bramhall House, 1959), 46.

4 Jerome Beatty, “Dexter Fellows: The Master of Ballyhoo," The American Magazine, March 1930. Found in Bandwagon (September-December 2013), 62.

5 John J. Wallis, Price V. Fishback, and Shawn Kantor, "Politics, Relief, and Reform: Roosevelt's Efforts to Control Corruption and Political Manipulation During the New Deal," in Corruption and Reform: Lessons From America's Economic History, eds. Edward L. Glaeser and Claudia Goldin (London: University of Chicago Press, 2006)

6 Ibid., 367-8.

7 David W. Maurer, The American Confidence Man (Springfield, IL: Charles C. Thomas, 1974), 203-4.

8 "Federal Tax Returns Being Closely Scrutinized by Revenue Collectors," Billboard, May 16, 1936, p. 3.

9 Cameron v. Ringling Bros. Barnum Bailey Combined Shows, Inc., State of Ohio, Court of Common Pleas, Hamilton County (April 11, 1940), 1940 Ohio Misc. LEXIS 416; 17 Ohio Op. 227; 31 Ohio L. Abs. 266, Lexis Nexis.

10 P. M. Silloway, "The Circus Goes Modernistic," Billboard, March 28, 1942, p. 36.

11 Robert C. Sweet, "The Circus: Institution in Continuity and Change." PhD diss., University of Missouri, 1970., 150.

12 David Hammarstrom, "How Much Does A Circus Need," Circus Review Vol. 8, No. 1 (Winter). Found in Sweet, "The Circus...", 162

13 “R-B Takes to Canvas," Billboard, May 19, 1934, p. 34.

14 See note 12 . 


\section{REFERENCES}

\section{PRIMARY SOURCES}

“AFA Gets 200 Endorsements" Billboard, April 10, 1937, p. 34.

“AFA Issues 'Unfair List"” Billboard, April 17, 1937, p.11.

Beal, George B. Through the Back Door of the Circus (Springfield, MA: McLoughlin Bros., Inc., 1938).

Beasley, Al D. Twentieth Century Peru (1899).

Beatty, Jerome. "Dexter Fellows: The Master of Ballyhoo," The American Magazine, March 1930. Found in Bandwagon (September-December 2013), 62.

Bel Geddes, Norman. "Streamlining the Circus" The New Republic, January 20, 1941.

“Big Show Flies AFA Banner" Billboard, June 5, 1937, p. 96.

Bliven, Bruce Jr., “Long Live the Circus!” The New Republic, May 22, 1939.

Braathen, Sverre. "The Sheet Anchor Failed" Bandwagon, Vol. 16, No. 3 (May/June 1972), pp. 27-32.

Bradna, Fred and Spence, Hartzell. The Big Top: My Forty Years with The Greatest Show on Earth (New York: Simon and Schuster, 1952).

"But the Show Didn't Go On" New York Times, July 3, 1938.

Cameron v. Ringling Bros. Barnum Bailey Combined Shows, Inc., State of Ohio, Court of Common Pleas, Hamilton County (April 11, 1940), 1940 Ohio Misc. LEXIS 416; 17 Ohio Op. 227; 31 Ohio L. Abs. 266, Lexis Nexis.

Chipman, Bert J. Hey Rube! (Bert J. Chipman, 1933).

"CIO Not Interested in Show Business Now, But Maybe Later" Billboard, March 20, 1937, p. 3. 
“A ‘Circus City' Falls-Why?” Billboard, July 2, 1938, p. 29.

“The Circus Does a 'Tunney'” Billboard, June 12, 1937, p. 39.

"Circus Parades, We Need Them" Washington Times, quoted in Billboard, September 1,1934 , p. 38.

“Clearing the Field” Billboard, October 14, 1922, p. 108.

“Cole Signs Closed Shop Contract With AFA; Minimum Wage Is \$40" Billboard, September 11, 1937, p. 3.

"Excerpts From Editorials and Letters Regarding Ringling-Barnum Closing" Billboard, July 9, 1938, p. 63.

“Federal Tax Returns Being Closely Scrutinized by Revenue Collectors," Billboard, May 16, 1936, p. 3.

"First Guns in Circus War Fired in the West" Show World, April 23, 1910 (vol. V, No. 18). Accessed at http://circushistory.org/ShowWorld/ShowWorld1910.htm

Fowler, Gene. Timber Line: A Story of Bonfils and Tammen (New York: Covici \& Friede, 1933).

"Friction with Business Office" Show World, July 27, 1907. Accessed at http://circushistory.org/ShowWorld/ShowWorld1907.htm

“Gasoline Gipsies of Circus Land” Literary Digest, April 25, 1931, p. 42.

“Graft and Immorality Condemned" Billboard, December 1, 1922, p. 19.

“Graft! Graft!! Graft!!” Billboard, December 2, 1922, p. 71.

“Grafting Police and Crooked County Officers” Billboard, October 21, 1922, p. 5.

“Green Questions Rights of Actors” New York Times, August 9, 1939.

“Half of Show Biz Jobless" Billboard, July 10, 1937, p. 4

Hamid, George A., Jr. Circus (New York: Sterling, 1950).

“Hartmann's Broadcast” Billboard, July 30, 1938, p. 29.

"How to Eliminate the Circus Pass Evil" Billboard, January 12, 1929. Accessed at http://circushistory.org/History/CircusPassEvil.htm 
“H-W Employees Form Independent Union" Billboard, July 10, 1937, p. 36.

“H-W Smashes Some Records in Chicago" Billboard, April 24, 1937, p.38.

Jahnsen, Oscar J. Interview by Alice King and Miriam Feingold Stein. 1976. Earl Warren Oral History Project. University of California Berkeley Bancroft Library, accessed at http://nma.berkeley.edu/ark:/28722/bk0005z1x6f.

Transcript pp. 38-9.

“James Anderson, Veteran Circus Man, In Feeble Health" Peru [Indiana] Daily Chronicle, June 21, 1910.

“Jerry Mugivan Tells How It Was Done” Billboard, March 19, 1921, 16.

"Just A Few Looks Into The Lives Of The Big Show Artists And Workers" Ringling Bros. and Barnum \& Bailey Magazine and Daily Review, Season of 1936, p.24.

Kline, Tiny. Circus Queen \& Tinker Bell: The Memoir of Tiny Kline, ed. Janet M. Davis (Chicago: University of Illinois Press, 2008).

Lambert, William (DeLavoye). Show Life in America (Will DeLavoye, 1925).

“Larger Shows Fare Best in 1937” Billboard, January 1, 1938, p. 74.

Lewis, Robert M., ed. From Travelling Show to Vaudeville: Theatrical Spectacle in America, 1830-1910 (Baltimore: Johns Hopkins University Press, 2003).

McKennon, Joe. Circus Lingo: Another Book by the Man Who Was With It (Sarasota, FL: Carnival Publishers of Sarasota, 1980).

-----. Horse Dung Trail: Saga of the American Circus (Sarasota, FL: Carnival Publishers of Sarasota, 1975).

----. Logistics of the American Circus: Written by a Man Who Was There (Sarasota, FL: Carnival Publishers of Sarasota, 1977).

Meeker, George. papers, Miami County Historical Society Museum, Peru, Indiana.

Nels, Juleus and Hanners, John. Papers and recordings, Circus Oral History Project, 1977-1981, private donation to author.

[No Title] Billboard, September 23, 1922, p. 5.

[No Title] Billboard, September 21, 1929, p. 52. 
[No Title] Billboard, November 27, 1937, p. 27.

[No Title] Variety, October 17, 1908, p. 14. Accessed at http://circushistory.org/History/Variety1906.htm\#1908

[No Title] Variety, May 17, 1923, p. 10. Accessed at http://www.archive.org/stream/variety70-192305\#page/n105/mode/2up/search/\%22Frank+Cook\%22

North, Henry Ringling and Hatch, Alden. The Circus Kings: Our Ringling Family Story (Garden City, NY: Doubleday \&Co., Inc., 1960).

"Observations of the Stroller," Billboard, June 5, 1909.

“Outdoor Forum" Billboard, November 4, 1922, p. 88.

“R.-B. and S.-F. Shows Battling in Frisco" Billboard, September 2, 1922, pp. 7, 10

“R-B Takes to Canvas," Billboard, May 19, 1934, p. 34.

Ringling, Charles. "Let's Get Together for a 'Graftless' 1923" Billboard, October 7, 1922, p. 53.

“Ringling Near-Capacity Houses First 4 Days at MSG" Billboard, April 17, 1937.

"Ringlings Send Flying Squad of 60 Men Against Hagenbeck" Variety, October 20, 1922, p. 8. Accessed at http://www.archive.org/stream/variety68-192210\#page/n103/mode/2up/search/Ringling

“'Save the Circus!' They Cry" New York Times, August 14, 1938.

"The Shady Side of the Circus Business" New York Tribune, October 1, 1922, Magazine section.

"Significant If True" Billboard, September 16, 1922, p. 64.

Silloway, P. M. “The Circus Goes Modernistic," Billboard, March 28, 1942, p. 36.

"The Social Security Act As It Affects Outdoor Amusement Fields" Billboard, March 20, 1937, p. 53.

----. March 27, 1937, p. 39.

----.. April 3, 1937, p. 44. 
"Stage Union Loses Its A.F.L. Charter" New York Times, July 15, 1939.

“Suppressing Bad Conditions” Billboard, September 23, 1922, p. 70.

Thompson, W. C. On the Road with a Circus (1903). Accessed at http://circushistory.org/History/OnRoad3.htm\#X.

"To Smoke Out the Local Graft Fixer" Billboard, October 14, 1922, p. 5.

“Union For Circus Workmen" Billboard, May 22, 1937, p. 3.

"Whitehead Chided on Actor's Policy" New York Times, July 13, 1939.

"WPA Boys in the Dough" Billboard, March 27, 1937.

"23\% of Federal Theater Performers are 'Phonies'” Billboard, January 23, 1937.

\section{SECONDARY SOURCES}

Abbott, Lynn and Seroff, Doug. Ragged but Right: Black Traveling Shows, "Coon Songs," and the Dark Pathway to Blues and Jazz (Jackson, MS: University Press of Mississippi, 2007.

Adams-Volpe, Judith A. "Circus and Wild West Exhibition" in The Greenwood Guide to American Popular Culture, eds. M. Thomas Inge and Dennis Hall (Westport, CT: Greenwood Press, 2002), p. 257.

Albrecht, Ernest J. A Ringling By Any Other Name: The Story of John Ringling North and His Circus (Metuchen, NJ: Scarecrow Press, Inc., 1989).

-----. From Barnum \& Bailey to Feld: The Creative Evolution of The Greatest Show on Earth (Jefferson, NC: McFarland\& Co., Inc., 2014).

Ballard, Charles E. Charles Edward "Ed" Ballard: A Story of Determination, SelfEducation, and Ultimate Success, comps. Janet Kirk Johnson and Anna Marie Borcia (C. E. Ballard Literary Trust, 1984).

Barenberg, Mark. "The Political Economy of the Wagner Act: Power, Symbol, and Workplace Cooperation," Harvard Law Review, Vol. 106, No. 7 (May 1993).

Bogdan, Robert. Review of The Circus Age: Culture and Society Under the American Big Top by Janet M. Davis, The American Historical Review, June 2003. 
Childers, James Saxon. "Inside Workings of a Great Circus" Bandwagon, Vol. 21, No. 1 (Jan.-Feb. 1977), 14-17. First published in Birmingham (Alabama) News Age Herald September 28, 1930.

Chindahl, George L. A History of the Circus in America (Caldwell, ID: Caxton Printers, Ltd., 1959).

Cohen, Lizabeth. Making a New Deal: Industrial Workers in Chicago, 1919-1939 (New York: Cambridge University Press, 1990).

Comte, Julien. "'Let the Federal Men Raid': Bootlegging and Prohibition Enforcement in Pittsburgh," Pennsylvania History, Vol. 77, No. 2 (Spring 2010): 166192, accessed March 17, 2015, doi: 10.1353/pnh.0.0021

Condon, Chalmer. "Benjamin E. Wallace's Winterquarters" Bandwagon, July-August 1964, 7-10.

Culhane, John. The American Circus: An Illustrated History (New York: Henry Holt and Co., 1990).

Davis, Janet M. The Circus Age: Culture \& Society Under the American Big Top (Chapel Hill: University of North Carolina Press, 2002).

Denning, Michael. The Cultural Front: The Laboring of American Culture in the Twentieth Century (London: Verso, 1996).

“The Depression and Industry Finances," Film Reference, http://www.filmreference.com/encyclopedia/Criticism-Ideology/GreatDepression-THE-DEPRESSION-AND-INDUSTRY-FINANCES.html

Dickstein, Morris. Dancing in the Dark: A Cultural History of the Great Depression (New York: W. W. Norton \& Company, 2009).

Fox, Charles P. A Ticket to the Circus: A Pictorial History of the Incredible Ringlings (New York: Bramhall House, 1959).

Geisst, Charles R. Monopolies in America: Empire Builders and Their Enemies, from Jay Gould to Bill Gates (New York: Oxford University Press, 2000).

Glaeser, Edward L. and Goldin, Claudia, eds. Corruption and Reform: Lessons from America's Economic History (London: University of Chicago Press, 2006).

Green, James R. The World of the Worker: Labor in Twentieth Century America, consulting ed. Eric Foner (New York: Hill and Wang, 1980). 
Halttunen, Karen, ed. A Companion to American Cultural History (Hoboken, NJ: John Wiley \& Sons, Ltd., 2008).

Hammarstrom, David L. Fall of the Big Top: The Vanishing American Circus (Jefferson, NC: McFarland \& Co., Inc., 2008).

----. Inside the Changing Circus: A Critic's Guide (Duncan, OK: BearManor Media, 2012).

Hanners, John. "It Was Play or Starve": Acting in the Nineteenth-Century American Popular Theatre (Bowling Green, OH: Bowling Green State University Popular Press, 1993).

Heale, M. J. Twentieth Century America: Politics and Power in the United States, 1900-1920 (New York: Oxford University Press, 2004).

Hofstadter, Richard. The Age of Reform: From Bryan to F. D. R. (New York: Random House, 1955).

Inciardi, James A. and Petersen, David M. "Gaff Joints and Shell Games: A Century of Circus Grift," Journal of Popular Culture Vol. VI No. 3 (Spring 1973): 591-606.

Jenkins, Philip. "'A Wide Open City:' Prostitution in Progressive Era Lancaster," Pennsylvania History, Vol. 65, No. 4 (Autumn 1998): 509-526, accessed March 17, 2015, http://jstor.org/stable/27774144.

Jensen, Dean. The Biggest, the Smallest, the Longest, the Shortest: A Chronicle of the American Circus from Its Heartland (Madison: Wisconsin House Book Publishers, 1975).

Krause, Paul. The Battle For Homestead, 1880-1892: Politics, Culture, and Steel (Pittsburgh: University of Pittsburgh Press, 1992).

Lenthall, Bruce. Radio's America: The Great Depression and the Rise of Modern Mass Culture (Chicago: University of Chicago Press, 2007).

Leuchtenburg, William E. The Perils of Prosperity, 1914-1932 (Chicago: University of Chicago Press, 1993).

Maurer, David W. The American Confidence Man (Springfield, IL: Charles C. Thomas, 1974).

McConnell, John H. A History of the Shrine Circus: Mystic Shriners Yankee Circus in Egypt (Detroit: Astley \& Ricketts, 1998). 
McGerr, Michael. A Fierce Discontent: The Rise and Fall of the Progressive Movement in America, 1870-1920 (New York: Oxford University Press, 2003).

Meeker George and Ferol, "Ben Wallace and the Early Circus in Peru, Indiana" 17th Annual Official Souvenir Program, Circus City Festival, 1976, 50-51.

Nasaw, David. Going Out: The Rise and Fall of Public Amusements (New York: BasicBooks, 1993).

Okrent, Daniel. Last Call: The Rise and Fall of Prohibition (New York: Scribner, 2010).

Parkinson, Robert L. Directory of American Circuses, 1793-2000 (Baraboo, WI: Circus World Museum, 2002).

Parkinson, Tom and Fox, Charles P. The Circus Moves By Rail (Newton, NJ: Carstens Publications, Inc., 1993).

Paulsen, George E. A Living Wage for the Forgotten Man: The Quest for Fair Labor Standards, 1933-1941 (London: Susquehanna University Press, 1996).

Pfening, Fred D., Jr., "How Wallace Bought Hagenbeck" Bandwagon, July-August, 1964, 11-12.

Register, Woody. The Kid of Coney Island: Fred Thompson and the Rise of American Amusements (New York: Oxford University Press, 2001)

Renoff, Gregory J. The Big Tent: The Traveling Circus in Georgia, 1820-1930 (Athens, GA: University of Georgia Press, 2008).

Sutherland, Edwin H. papers, private donation to author.

Sweet, Robert C. "The Circus: Institution in Continuity and Change." PhD diss., University of Missouri, 1970.

Sweet, Robert C. and Habenstein, Robert W. "Some Perspectives on the Circus in Transition," Journal of Popular Culture Vol. VI No. 3 (Spring 1973): 583590.

Talburt, Lane. "Amid Ruins of 1938 Season Last Two Railers Made Big Showing in Atlanta" Bandwagon (November/December 2010), 47-51.

Weeks, David C. Ringling: The Florida Years, 1911-1936 (Gainesville, FL: University Press of Florida, 1993).

Wiebe, Robert H. The Search for Order, 1877-1920 (New York: Hill \& Wang, 1967). 


\title{
CURRICULUM VITA
}

\author{
NAME: $\quad$ Matt S. Holdzkom \\ ADDRESS: 2832 W. Preserve Ln. \\ Muncie, IN 47304 \\ DOB: $\quad$ Fort Wayne, Indiana - January 8, 1981 \\ EDUCATION \\ \& TRAINING: $\quad$ B.F.A., Printmaking \\ Pacific Northwest College of Art \\ 2002-2005 \\ Processing Intern, Special Collections \\ Filson Historical Society \\ Fall 2014 \\ Collections Intern; Curator of Collections \\ Kentucky Science Center \\ Fall 2013; Summer 2014 \\ Digital Curation Intern \\ Anne Braden Institute for Social Justice \\ Summer 2014 \\ Assistant Curator \\ Architectural Heritage Center \\ 2010-2011
}

